\title{
ANALIZA KORIŠTENJA I PRIHVAĆANJA INTEGRIRANOG KNJIŽNIČNOG SUSTAVA NACIONALNE I SVEUČILIŠNE KNJIŽNICE U ZAGREBU TE VISOKOŠKOLSKIH I ZNANSTVENIH KNJIŽNICA REPUBLIKE HRVATSKE
}

\author{
ANALYSIS OF USE AND ACCEPTANCE \\ OF THE INTEGRATED LIBRARY SYSTEM OF \\ THE NATIONAL AND UNIVERSITY LIBRARY IN ZAGEB \\ AND ACADEMIC AND RESEARCH LIBRARIES \\ IN THE REPUBLIC OF CROATIA
}

\section{Dijana Machala}

Nacionalna i sveučilišna knjižnica u Zagrebu

dmachala@nsk.hr

UDK / UDC 025.3:027.7:027.54(497.5 Zagreb)

Izvorni znanstveni rad / Original scientific paper

Primljeno / Received: 9. 4. 2018.

Prihvaćeno / Accepted: 9. 6. 2018.

\section{Sažetak}

Cilj. Cilj je rada utvrditi postoji li mjera uspješnosti integriranog knjižničnog sustava Aleph ${ }^{1}$, odnosno istražiti u kojoj mjeri integrirane knjižnice iz sustava znanosti i visokog obrazovanja Republike Hrvatske prihvaćaju i koriste zajednički knjižnični program Aleph te koji čimbenici utječu na njihovu namjeru da se i u budućnosti nastave koristiti tim informacijskim sustavom. Provedba istraživanja procjene uspješnosti integriranog knjižničnog sustava Aleph nije predmetom ovog rada.

1 Integrirani knjižnični sustav Nacionalne i sveučilišne knjižnice u Zagrebu te visokoškolskih i znanstvenih knjižnica Republike Hrvatske naziv je mreže knjižnica iz sustava znanosti i visokog obrazovanja Republike Hrvatske koje koriste integrirani knjižnični program Aleph. Dalje u tekstu: Integrirani knjižnični sustav Aleph.

Vjesnik bibliotekara Hrvatske 61, 1(2018), 435-467

ISSN 0507-1925

(C) VBH 2018. 
Pristup/metodologija/dizajn. Metodom deskriptivne statistike analizirani su kvantitativni podaci dobiveni SQL-upitima na baze integriranog knjižničnog sustava Aleph, odnosno izravnim uvidom u podatke iz programskih tablica. Na taj način prikupljeni su kvantitativni pokazatelji o veličini, značajkama i aktivnostima sustava koji se bilježe u programske i izvještajne tablice sustava. Primjenom teorijskog modela prihvaćanja tehnologije ispitalo se postoje li i, ako postoje, koji su to čimbenici koji utječu na namjeru voditelja knjižnica da prihvate i koriste implementirani integrirani knjižnični sustav Aleph i može li se utvrditi mjeru, tj. dimenzije uspješnosti samog informacijskog sustava. U tu svrhu testirana je primjena metodologije prilagođenog UTAUT-modela, pri čemu su korišteni podaci prikupljeni online anketom kojom su ispitani stavovi voditelja knjižnica o stupnju njihova zadovoljstva programskim modulima knjižničnog programa Aleph te uslugama koje podržavaju rad integriranog knjižničnog sustava Aleph.

Rezultati. Rezultati istraživanja pokazuju da postoji korelacija između percepcije knjižničara o očekivanoj učinkovitosti knjižničnog programa Aleph i same namjere knjižničara da prihvate i nastave koristiti integrirani knjižnični sustav Aleph. Rezultati istraživanja navode na zaključak da bismo mjeru uspješnosti integriranog knjižničnog sustava Aleph mogli tražiti u segmentu povećane knjižnične učinkovitosti te razvoja knjižničnih usluga, a koje nastaju kao rezultat korištenja i primjene integriranog knjižničnog sustava Aleph.

Ograničenja. Rezultate istraživanja bilo bi poželjno potvrditi provedbom namjenski dizajniranog metodološkog upitnika sukladno UTAUT-modelu te proširiti broj vrijednosnih atributa u odnosu na specifičnosti informacijskog sustava Aleph. Također, istraživanje je provedeno na malom uzorku ispitanika te bi rezultate bilo poželjno potvrditi na većem ispitnom uzorku, a stratifikacija ispitnog uzorka prema vrsti knjižnice, radnom statusu knjižničnih djelatnika ili prethodnom iskustvu mogla bi biti obuhvatnija.

Praktična primjena. Rezultati istraživanja mogu biti od koristi donosiocima razvojnih politika u području knjižnične automatizacije te knjižnične suradnje.

Originalnost/vrijednost. U radu se prvi put analiziraju rezultati procesa automatizacije knjižničnog poslovanja visokoškolskih knjižnica te se procjenjuje korištenje i prihvaćanje integriranog knjižničnog sustava Aleph.

Ključne riječi: integrirani knjižnični sustav Aleph, knjižnična automatizacija, prihvaćanje i korištenje tehnologije, UTAUT-model.

\section{Abstract}

Purpose. The aim of the paper is to analyze the measure of success of the integrated library system Aleph, i.e. to assess the acceptance and use of the integrated library system Aleph by integrated academic and research libraries in Croatia, and to analyze the motivational factors that influence the intention to use that information system in the future. Assessment of information system success is not the topic of our research. 
Approach/methodology/design. The method of descriptive statistics has been used to analyze quantitative data obtained by SQL queries to the library system database or by direct access into the program and system files and tables. The method enabled the collection of quantitative indicators of the size, characteristics and activities of the system that are recorded in the system files. The paper seeks to assess the acceptance and use of the integrated library system Aleph by academic and research libraries in Croatia and to analyze the measure of success of that integrated information system. For this purpose, a modified UTAUT model has been tested to analyze data gathered by an online opinion survey of academic library directors who were asked to estimate their level of satisfaction with the Aleph integrated library system modules and services.

Findings. Research results show a correlation between the perception of expected efficiency of the library information system Aleph and the intention of libraries to accept and to continue to use a library integrated system in the future. Research results lead to the conclusion that the measure of success of the integrated library system is visible in the increased efficiency and productivity of library services that resulted from direct use of the implemented integrated library system Aleph.

Practical implications. Research results can be useful to library development policy makers in the field of library automation and co-operation.

Limitations. It would be appropriate to confirm the research results by a designed questionnaire according to the UTAUT model, expanding attributed values according to specifics of the integrated information system Aleph. Research has been conducted upon a small sample of respondents, so it would be desirable to confirm research results on a much greater research sample. Stratification by library type, working status of librarians or previous experience could be more comprehensive.

Originality/value. Assessment of acceptance and use of the integrated library system Aleph in Croatian academic and research libraries has been analyzed for the first time.

Keywords: integrated library systems Aleph, library automation, acceptance and use of information technology, UTAUT model.

\section{Uvod}

Knjižnice u Republici Hrvatskoj međusobno surađuju i povezuju se, a umrežavanje primjenom zajedničkog informacijskog knjižničnog sustava ostvaruje se prema načelima racionalizacije poslovanja na temelju standardizacije postupaka obrade i protoka građe i informacija te s ciljem zadovoljenja potreba krajnjih korisnika i usklađivanja razvojnih ciljeva i aktivnosti knjižnica. Postupak umrežavanja ili povezivanja knjižnica složen je proces, pri čemu je bitna sastavnica tog procesa provedba vrednovanja. Valja istaknuti da se vrednovanje rezultata uspo- 
stavljene suradnje ili povezivanja smatra značajnim ne samo za same sudionike sustava već i za donosioce politika daljnjeg razvoja knjižničnog sustava. Postupak vrednovanja trebao bi omogućiti pojedinačnim knjižnicama da statističke podatke koriste za učinkovito upravljanje te da se statistički podaci koriste na nacionalnoj i međunarodnoj razini poradi iskazivanja pokazatelja učinka knjižnica na pozitivne trendove u području društveno-ekonomskog i kulturnog razvoja. ${ }^{2}$

U središtu je interesa ovog rada utvrditi okvir za provedbu analize uspješnosti integriranog knjižničnog sustava Aleph koji je ostvaren postupkom implementacije zajedničkog integriranog knjižničnog programa Aleph te automatizacijom knjižničnog poslovanja 43 knjižnice iz sustava znanosti i visokog obrazovanja.

Istraživanje se temelji na analizi kvantitativnih podataka dobivenih iz programskih datoteka sustava te na analizi podataka koji su prikupljeni anketiranjem stavova voditelja visokoškolskih knjižnica o primjeni i korištenju integriranog knjižničnog sustava visokoškolskih i znanstvenih knjižnica čija su poslovanja objedinjena zajedničkim integriranim knjižničnim programom Aleph.

\section{Knjižnični informacijski sustav - opći prikaz}

Integrirani knjižnični sustav Nacionalne i sveučilišne knjižnice u Zagrebu te visokoškolskih i znanstvenih knjižnica Republike Hrvatske čine ukupno 43 knjižnice iz sustava znanosti i visokog obrazovanja. Uz Nacionalnu i sveučilišnu knjižnicu u Zagrebu, u sustavu je povezano 28 (65 \% od ukupno 42) visokoškolskih knjižnica Sveučilišta u Zagrebu, Sveučilišna knjižnica Hrvatskog katoličkog sveučilišta, 11 knjižnica znanstvenih instituta te dvije veleučilišne knjižnice (Veleučilište u Karlovcu i Veleučilište Velika Gorica). ${ }^{3}$

Sve knjižnice članice integriranog knjižničnog sustava Aleph temelje svoje knjižnično poslovanje na primjeni zajedničkog knjižničnog programa Aleph500 (Ex Libris), a integracija njihovih knjižničnih poslovanja u zajedničkom sustavu uspostavljena je provedbom Projekta implementacije Integriranog knjižničnog sustava Aleph u Nacionalnoj i sveučilišnoj knjižnici u Zagrebu i knjižnicama sastavnicama Sveučilišta u Zagrebu i znanstvenih instituta ${ }^{4}$ 2011. godine.

\footnotetext{
2 Usp. IFLA Manifest o knjižničnoj statistici. // Vjesnik bibliotekara Hrvatske 55, 1(2012), str. 137.

3 Prema podacima Upisnika znanstvenih organizacija Agencije za znanost i visoko obrazovanje, koji je dostupan na adresi http://azvo.hr/hr/znanost/znanstvene-organizacije, u Republici Hrvatskoj u 2018. godini registrirano je ukupno 25 javnih instituta, 87 visokih učilišta te 70 pravnih osoba izvan sustava visokog obrazovanja i javnih znanstvenih instituta koje su registrirale znanstvenu djelatnost. Od ukupno 182 ustanove iz sustava znanosti i visokog obrazovanja RH, za potrebe knjižničnog poslovanja njih 43 (24\%) koristi knjižnični program Aleph. U ostalim ustanovama u upotrebi je neki od sljedećih knjižničnih programa: CROLIST, Metel, ISIS, ZaKi ili Koha.

4 Usp. Machala, D.; L. Machala. Implementacija integriranog knjižničnog sustava Aleph u Nacionalnoj i sveučilišnoj knjižnici u Zagrebu i knjižnicama sastavnicama Sveučilišta u Zagrebu i
} 
Implementacijom integriranog knjižničnog programa Aleph svim članicama sustava omogućeno je korištenje programskih modula za katalogizaciju, nabavu i cirkulaciju, razvijene su pojedinačne instance WebPAC-sučelja za pretraživanje knjižničnih fondova te su omogućene funkcionalnosti kontrole pristizanja serijskih publikacija, izrade statističkih izvještaja, biltena te izvještajnih dokumenata.

Podaci sustava bilježe se u nekoliko bibliografskih baza (NSK01 i ZAG01), nadređenu normativnu bazu (NSK10) te više virtualnih i administrativnih baza. Projekt implementacije sastojao se od procesa konverzije i migracije bibliografskih zapisa iz knjižničnih programa u primjeni (ako su se koristili), funkcionalnoj implementaciji sustava, implementaciji poslovnih politika na razini cijelog sustava, ali i na razini pojedine knjižnice (vrijeme posudbe, korisnička prava i sl.) te edukaciji za rad u novom sustavu. Osim automatizacije knjižničnog poslovanja, zajednički informacijski knjižnični sustav integriranim knjižnicama omogućuje međusobnu razmjenu zapisa, razmjenu zapisa putem mrežnih protokola s knjižničnim katalozima u svijetu, ujednačenu primjenu standarda putem zajedničkih smjernica za rad u sustavu, osnaživanje ljudskih kapaciteta putem provedbe programa edukacije za rad u sustavu te stalnom savjetodavnom i tehničkom podrškom za rad. Nacionalna i sveučilišna knjižnica u Zagrebu matično je središte te koordinator integriranog knjižničnog sustava Aleph, a sve članice sustava međusobno uređuju svoje obveze i prava na temelju zajedničkog Sporazuma o uređivanju odnosa NSK $i$ sudionika u Integriranom knjižničnom sustavu temeljenom na zajedničkom knjižničnom programu. ${ }^{5}$

Premda se suradnja s knjižnicama članicama odvija svakodnevno, sveobuhvatna analiza vrednovanja prihvaćanja i korištenja te zadovoljstva korištenjem integriranog knjižničnog sustava Aleph u knjižnicama članicama sve do sada nije bila učinjena. Cilj je takve analize ostvarivanje pretpostavki za oblikovanje daljnjih razvojnih ciljeva uspostavljene suradnje te planiranje daljnjeg razvoja sustava.

\section{Teorijski okvir za procjenu uspješnosti informacijskih sustava i automatizacije}

Prema definiciji Američkog knjižničnog udruženja automatizacija je primjena računala i druge tehnologije u procesu nabave, organizacije, pohrane, pretraživanja i diseminacije informacija. ${ }^{6}$ Svrha je automatizacije knjižničnog poslova-

znanstvenih instituta : posebnosti implementacijskog procesa. // Zbornik radova 12. dana specijalnih i visokoškolskih knjižnica, Opatija, 11.-14. svibnja 2011. Zagreb: Hrvatsko knjižničarsko društvo, 2013. Str. 330-343.

5 Sporazum o uređivanju odnosa NSK i sudionika u Integriranom knjižničnom sustavu temeljenom na zajedničkom knjižničnom programu. Zagreb: Nacionalna i sveučilišna knjižnica u Zagrebu, 2011.

6 Usp. The ALA glossary of library and information science / Heartsill Young (ed.). Chicago: American Library Association, 1983. Str. 18. 
nja da utječe na brže i jednostavnije pretraživanje informacija nego što bi to bilo moguće ručno. Premda se počeci knjižnične automatizacije u tehnološki razvijenim angloameričkim zemljama vezuju uz sredinu 60 -ih godina 20 . stoljeća ${ }^{7}$, sustavan proces automatizacije $\mathrm{u}$ hrvatskome knjižničarstvu počinje tek petnaestak godina kasnije. Naime Nacionalna i sveučilišna knjižnica u Zagrebu započela je informatizaciju svog poslovanja 1980. godine na temelju Projekta informatizacije NSB iz $1979^{8}$, a taj će se početni zaostatak u automatizaciji i tehnološkom razvoju hrvatskih knjižnica nastojati što prije nadoknaditi. Borgman ${ }^{9}$ stoga ističe kako su promjena političkog sustava 90 -ih godina prošlog stoljeća i posljedično ukidanje embarga na uvoz informacijske tehnologije sa Zapada utjecali na to da zemlje središnje i istočne Europe ubrzaju procese informatizacije vladinog i javnog sektora s ciljem izgradnje novih demokratskih politika u okviru ekonomskih, društvenih i javnih institucija. Borgman jasno ukazuje na povezanost ulaganja u automatizaciju i informatizaciju poslovanja knjižnica s razvojem novih nacionalnih razvojnih smjernica i planova izgradnje demokratskih javnih institucija, no ističe kako je u odnosu na knjižnični sektor potrebno istražiti praktične razloge $\mathrm{i}$ ciljeve takve usmjerenosti na ubrzanu automatizaciju. ${ }^{10}$ Nacionalna i sveučilišna knjižnica započela je razvojem hrvatskog knjižničnog sustava $C R O L I S T^{11}$ sustavnu automatizaciju koja je trajala sve do 2007. godine, kada je odlučeno o nabavi međunarodno prihvaćenog integriranog knjižničnog sustava Voyager (Endeavor), a potom Aleph (ExLibris). Odluka o primjeni novog integriranog knjižničnog sustava temeljila se, među inim, i na analizi stanja automatizacije hrvatskih visokoškolskih knjižnica, koja je ukazivala na velika odstupanja u stupnju automatizacije

\footnotetext{
7 Usp. Line, M. B. Forty years of library automation: a personal reflection. // Program 40, 2(2006), 118-122.

8 Usp. Integralni informacijski sustav NSB / uredili V. Jelenković, V. Lešaja, I. Mihel, Ž. Rajter, D. Skender, J. Stipanov, M. Willer. Zagreb: Nacionalna i sveučilišna knjižnica u Zagrebu, 1990. Str. 1.

9 Usp. Borgman, C. L. Automation is the answer, but what is the question? Progress and prospects for Central and Eastern European Libraries. // Journal of Documentation 52, 3(1996), 252-295.

10 „Libraries were among the first organizations in the region to obtain Internet connections. Concurrently, they are acquiring computer systems to automate their internal processes, build databases and provide services on their national computer networks. The rapid adoption of information technology suggests that they see it as an answer to their problems - but what problems do they expect these new technologies to solve? Do they expect automation to improve access to collections by users? To increase the audience for their services? To enhance their role in the educational system? To enhance co-operation among institutions? To improve the internal efficiencies of individual libraries? To provide management information? To create national information infrastructures for service delivery? To enhance international exchange of resources and services? To modernize and gain prestige?" Isto, str. 253.

11 Usp. Skender, D.; M. Willer. Computer-based library systems in the National and University Library in Zagreb. // Program 20, 1(1986), 82-85. ; Usp. Willer, M. CROLIST : Croatian library and information system. // VINE 24, 4(1994), 39-44.
} 
knjižnica na pojedinim hrvatskim sveučilištima. ${ }^{12}$ Kao učinak primjene novog integriranog knjižničnog programa u knjižnicama iz sustava visokog obrazovanja i znanosti Republike Hrvatske, očekivalo se smanjenje uočenih nejednakosti u stupnju automatizacije visokoškolskih knjižnica te prinos snažnijoj informacijskoj integraciji hrvatskih sveučilišta. Proces implementacije programa Voyager, a potom i prelazak na program Aleph, ostvaren je 2011. godine na Sveučilištu u Zagrebu, pri čemu je program Aleph implementiran u 38 hrvatskih knjižnica iz sustava znanosti i visokog obrazovanja. ${ }^{13}$ Danas su u integriranom knjižničnom sustavu Aleph integrirane 43 knjižnice, uključujući Nacionalnu i sveučilišnu knjižnicu. Od ukupno 43 knjižnice Sveučilišta u Zagrebu, njih 28 (65 \%) prihvatilo je Aleph, dvije visokoškolske knjižnice nastavile su rad u CROLIST-u, dvije su knjižnice implementirale $K o h u^{14}$, šest knjižnica nastavilo je koristiti Metel, a pet knjižnica ZaKi. ${ }^{15}$ Osim visokoškolskih knjižnica Sveučilišta u Zagrebu $(\mathrm{N}=28)$, integrirani knjižnični program Aleph implementiran je i u 11 knjižnica znanstvenih instituta, dvije veleučilišne knjižnice te jednu sveučilišnu i jednu nacionalnu knjižnicu.

Kako bismo mogli pristupiti oblikovanju okvira za procjenu uspješnosti uspostavljenog knjižničnog informacijskog sustava Aleph, potrebno je razumjeti značajke procesa automatizacije na kojem počiva umrežavanje knjižnica. Lynch ${ }^{16}$ do 2000. godine sistematizira tri razdoblja knjižnične automatizacije. Prvo razdoblje automatizacije odnosi se na razdoblje uvođenja računala u knjižnice, tj. provedbu informatizacije knjižničnih procesa. Drugo razdoblje automatizacije obilježeno je pojavom mrežnog javnog pristupa informacijama, tj. razvojem javno dostupnih knjižničnih kataloga ili OPAC-a i mrežnih knjižničnih usluga. Treće razdoblje automatizacije, prema Lynchu, obilježio je prijelaz s tiskane na elektroničku gra-

12 U okviru projekta „Uvođenje knjižničnog sustava Voyager u knjižnice sveučilišta u Republici Hrvatskoj 2007. godine“ voditeljice Dubravke Skender provedena je anketa o stanju automatizacije poslovanja sveučilišnih i visokoškolskih knjižnica hrvatskih sveučilišta. Rezultati ankete dostupni su na mrežnoj stranici Članovi skupine za uvođenje knjižničnog sustava Voyager u knjižnice sveučilišta u Hrvatskoj. [citirano: 2018-06-08]. Dostupno na: http://stari.nsk.hr/di/knjizvoy. asp.

13 Usp. Machala, D. Integrirani knjižnični sustav Nacionalne i sveučilišne knjižnice u Zagrebu te visokoškolskih i znanstvenih knjižnica RH: konferencija korisnika, Zagreb, 4. listopada 2011. [citirano: 2018-05-31]. Dostupno na: http://iks.nsk.hr/wp-content/uploads/2011/09/Integrirani-knji\%C5\%ni\%C4\%8Dni-sustavDM1.pptx.

14 Usp. Macan, B.; G. V. Fernández; J. Stojanovski. Open source solutions for libraries: ABCD vs Koha. // Program 47, 2(2013), 136-154. ; Usp. Vrkić, D.; J. Lisek; M. Glavica. Zaplesala je ovo ljeto: implementacija Kohe u knjižnični sustav Fakulteta elektrotehnike i računarstva: prvi dio. // Vjesnik bibliotekara Hrvatske 55, 3-4(2013), 1-16.

15 Usp. Giunio; K.; D. Polanski; M. Šupraha-Perišić. Kooperativna katalogizacija u knjižničnom sustavu ZaKi: u praksi mreže knjižnica. // Vjesnik Bibliotekara Hrvatske 58, 1-2(2015), 189-208. [citirano 2018-03-31]. Dostupno na: http://www.hkdrustvo.hr/vjesnik-bibliotekara-hrvatske/index.php/vbh/article/view/62/57.

16 Usp. Lynch, C. From automation to transformation: forty years of libraries and information technology in Higher education. // EDUCAUSE Review 35, 1(2000), 60-68. 
đu, odnosno razvoj digitalizacije i digitalnih usluga. Lynch zaključuje kako sljedeći korak u automatizaciji treba biti cjelovita transformacija, istinska promjena u poslovanjima visokoškolskih knjižnica, nastala kao rezultat mogućnosti novih informacijskih tehnologija, kao i promijenjenog visokoobrazovnog konteksta. Usporedno $\mathrm{s}$ automatizacijom pratimo i razvoj sistemskoga knjižničarstva, i to od onoga trenutka kada knjižnični informacijski sustavi postaju općeprihvaćeni, a integrirani knjižnični programi počinju se podržavati u knjižnicama lokalno. ${ }^{17}$ Brojna istraživanja ${ }^{18}$ koja analiziraju današnje potrebe u području sistemskoga knjižničarstva ističu pojavu sve veće diversifikacije uloga koje se očekuju od sistemskih knjižničara pri obavljaju zadataka u okviru zahtjeva suvremenih, tehnološki zrelih knjižnica. Ti se zahtjevi u okviru sistemskoga knjižničarstva najčešće grupiraju u tri kategorije: aktivnosti upravljanja knjižničnim informacijskim sustavom, aktivnosti razvoja i održavanja mrežnih usluga te aktivnosti razvoja digitalne knjižnice, tj. digitalnog knjižničarstva. Područje našeg istraživanja u tom će se smislu ograničiti na prvotni aspekt sistemskoga knjižničarstva, tj. na primjenu i upravljanje knjižničnim informacijskim sustavima.

Primjena informacijske tehnologije često se smatra istoznačnicom za izravan napredak i razvoj same organizacije te se njezino prihvaćanje i primjena unutar organizacije smatra neupitnim. Kako je dimenzije (konstrukte) procjene uspješnosti informacijski sustava kao što su kvaliteta, zadovoljstvo ili uspjeh teško objektivizirati, tako su istraživanja motivacijskih čimbenika prihvaćanja ili korištenja nove tehnologije danas sve značajnija, a počesto se smatraju i jednim od zrelijih istraživačkih segmenta u području teorije informacijskih sustava. ${ }^{19}$

\subsection{Teorijski modeli prihvaćanja i korištenja tehnologije}

Prvotno se uspješnost informacijskih sustava nastojala izraziti financijsko-ekonomskim pokazateljima, pri čemu se posebno ističu vrijednosni indikatori kao što su povrat ulaganja (engl. return on investment - ROI), uravnotežena bodovna kartica (engl. balanced scorecards) ili banchmarking. Međutim uspješnost poslovnog modela samo je jedan od segmenata u okviru kojih možemo procjenjivati uspješnost prihvaćanja i korištenja informacijske tehnologije.

17 Usp. Czaikowski Underhill, M.; L. Burkey Wade. Making a career shift. // Jump-start your career as a digital librarian: a LITA guide / edited by Jane Monson. Chicago: ALA, 2013. Str. 64.

18 Usp. Ratledge, D.; C. Sproles. An analysis of changing role of systems librarians. // Library Hi Tech 35, 2(2017), 303-311. ; Usp. Choi, Y.; E. Rasmussen. What qualifications and skills are important for digital librarian positions in academic libraries? A job advertisment analysis. // The Journal of Academic Librarianship 35, 5(2009), 457-467.

19 Usp. Williams, M.; R. Nripendra; D. Yogesh. The Unified Theory Of Acceptance and Use of Technology (UTAUT): a literature review. // Journal of Enterprise Information Management 28(2015), 443-488. ; Usp. Venkatesh, V.; M. G. Morris; G. B. Davis; F. D. Davis. User acceptance of information technology: toward a unified view. // MIS Quarterly 27, 3(2003), 425-478. 
Kvaliteta informacijskog sustava u segmentu tehničke i programske izvedbe ne korelira uvijek nužno s ukupnim zadovoljstvom korisnika te njegovom motivacijom da koristi određeni informacijski sustav. Konstrukti za vrednovanje prihvaćanja i korištenja tehnologije stoga se sve češće traže u bihevioralnom pristupu, odnosno u istraživanjima ponašanja korisnika, zadovoljstvu korisnika novom tehnologijom, utjecaju tehnologije na pojedinca ili organizaciju te, općenito, utjecaju na društvo. U tom području razvijeni su brojni teorijski modeli predviđanja prihvaćanja i korištenja tehnologije, poput Modela prihvaćanja tehnologije (engl. Technology acceptance model - TAM) ${ }^{20}$, Teorije razložne akcije (engl. Theory of reasoned action - TRA) ${ }^{21}$, Teorije planiranog ponašanja (engl. Theory of planned behavior - TPB) ${ }^{22} \mathrm{i} \mathrm{dr}$.

Davisov teorijski Model prihvaćanja tehnologije $\mathrm{e}^{23}$, koji u sebi obuhvaća TRAi TPB-teorije, uvodi skalu od dvije varijable, percipirane korisnosti i percipirane jednostavnosti korištenja, kao bitne odrednice predikcije i mjerenja prihvaćanja tehnologije kod korisnika. Percipiranu korisnost Davis definira kao stupanj vjerovanja osobe da će upotreba određenog sustava poboljšati njegovu ili njezinu radnu sposobnost ${ }^{24}$, a koja će mu u kontekstu organizacije priskrbiti određenu korist (povišicu, napredak, bonus i sl.). S druge pak strane, percipirana se jednostavnost korištenja odnosi na stupanj vjerovanja osobe da će određeni sustav koristiti bez većeg napora. ${ }^{25}$ Praktičnu primjenu tog teorijskog modela nalazimo u različitim indikatorima vrednovanja, poput metode analize troškova i koristi (engl. cost-benefit).

\subsection{Modeli uspješnosti informacijskih sustava (DeLoneov i McLeanov model uspješnosti)}

DeLone i McLean ${ }^{26}$ razvijaju teorijski model za mjerenje uspješnosti informacijskih sustava (D\&M IS success model) koji polazi od sinteze dotadašnjih defini-

20 Usp. Davis, F. D. Perceived usefulness, perceived ease of use, and user acceptance of information technology. // MIS Quarterly 13, 3(1989), 319-340.

${ }^{21}$ Usp. Fishbein, M.; I. Ajzen. Belief, attitude, intention and behavior : an introduction to theory and research, reading. MA: Addison-Wesley, 1975. ; također Usp. Ajzen, I.; M. Fishbein. Understanding attitudes and predicting social behavior. Englewood Cliffs, NJ: Prentice-Hall, 1980.

${ }^{22}$ Usp. Ajzen I. The theory of planned behavior. // Organizational Behavior and Human Decission Processess 50, (1991), 179-211.

23 Davis, F. D. Nav. dj., str. 319-340

24 Isto, str. 320.

25 Isto, str. 320.

26 Usp. DeLone W. H.; E. R. McLean. Information systems success : the quest for the dependent variable. // Information Systems Research 3, 1(1992), 60-95. ; Usp. DeLone, W. H.; E. R. McLean. Information systems success revisited. // Proceedings of the 35th Hawaii International Conference on System Sciences / ed. Sprague Jr R. H. IEEE Computer Society, Hawaii, US., 2002. Str. 
cija uspješnosti informacijskih sustava i njihovih uzročnih varijabli te identificira šest dimenzija uspješnosti informacijskog sustava: kvaliteta informacija, kvaliteta sustava, kvaliteta usluge, korištenje (namjera korištenja), zadovoljstvo korisnika i netokorist, tj. dobit. Prema D\&M-modelu uspješnost informacijskog sustava može se procjenjivati u dimenzijama kvalitete informacija, kvalitete sustava i kvalitete usluge, a njihove značajke utječu na daljnje korištenje ili namjeru korištenja te zadovoljstvo korisnika. Kao rezultat korištenja sustava postiže se određena dobit ili korist. Dobit će (pozitivno ili negativno) utjecati na zadovoljstvo korisnika te daljnje korištenje informacijskog sustava. Petter, DeLone i McLean ${ }^{27}$ naposljetku zaključuju da bi mjerenje uspješnosti informacijskog sustava trebalo biti holistički proces te da provedba istraživanja na temelju jedne od sastavnica toga modela navodi na necjelovite, a počesto i na krive zaključke.

$O$ važnosti primjene višedimenzionalnog pristupa u području mjerenja uspješnosti informacijskih sustava, tj. vrednovanja prihvaćanja i korištenja tehnologije, nalazimo i u Sriće i Spremića ${ }^{28}$ koji procjenjivanje uspješnosti informacijskog sustava sagledavaju u cjelini njegovih sastavnica: materijalno-tehničke, tj. hardvera; nematerijalne, odnosno softvera; ljudskih resursa ili lifewarea; komunikacijske tehnologije ili netwarea te organizacije, odnosno orgwarea.

O složenosti procesa te istraživačkim pitanjima procesa vrednovanja informacijskog sustava, oprimjerujući to na sustavu digitalne knjižnice, izlagao je Saračević ${ }^{29}$, istaknuvši kako se složeni informacijski sustavi ne mogu procjenjivati samo iz jednog aspekta. Saračević izdvaja vrijednosne elemente grupirane u dvije kategorije: korisnički i sistemski usmjerene pristupe. Korisnički usmjerene vrijednosne elemente dijeli na konstrukte u odnosu na vrednovanje društvene razine (zadovoljava li digitalna knjižnica potrebama, zahtjevima i ulogama društva ili zajednice), institucijske razine (podržava li digitalna knjižnica institucijsku ili organizacijsku misiju i cilj, uklapa li se u ostale institucijske resurse), osobne razine (podržava li digitalna knjižnica informacijske potrebe, zadaće i aktivnosti korisnika ili grupe korisnika) te razinu sučelja (pruža li sučelje potporu pristupu, pretraživanju, pregledavanju i međudjelovanju s digitalnom knjižnicom, a pitanje se može procjenjivati u jednom ili oba smjera - iz korisnički i/ili sistemski orijentiranog smjera). Pod sistemski usmjerene dimenzije vrednovanja Saračević u nastavku na-

2966-2976. Doi: 10.1109/HICSS.2002.994345 ; Usp. DeLone, W. H.; E. R. McLean. The DeLone and McLean model of information systems success: a ten-year update. // Journal of Management Information Systems 19, 4(2003), 9-30.

27 Usp. Petter, S.; W. DeLone; E. McLean. Measuring information systems success: models, dimensions, measured, and interrelationships. // European Journal of Information Systems 17(2008), 236-263.

28 Usp. Srića, V.; M. Spremić. Informacijskom tehnologijom do poslovnog uspjeha. Zagreb : Sinergija, 2000.

29 Usp. Saračević, T. Digital library evaluation: toward an evolution of concepts. // Library Trends 49, 3(2000), 350-369. 
vodi inženjerstvo (kakva je tehnička izvedba sustava), izvedbu (uspješnost izvedbe algoritama, procedura i sl.) te sadržaj (sadržajna reprezentativnost, selektivnost i organiziranost sadržaja).

Ono što Saračević nadalje smatra ključnim jest nužnost iznalaženja načina kako oba pristupa, korisnički usmjereni te sistemski usmjereni pristup, obuhvatiti prilikom vrednovanja informacijskog sustava.

\subsection{UTAUT-model prihvaćanja i korištenja tehnologije}

$\mathrm{S}$ ciljem sinteze razvijenih teorijskih modela te harmoniziranja rezultata istraživanja prihvaćanja i korištenja tehnologije, Venkatesh, Morris, Davis i Davis ${ }^{30}$ razvili su Objedinjeni teorijski model prihvaćanja i korištenja tehnologije (engl. The Unified Theory of Acceptance and Use of Technology - UTAUT). Objedinjeni model prihvaćanja i korištenja tehnologije (UTAUT) predlaže predviđanje prihvaćanja tehnologije u četiri jezgrena konstrukta: očekivana učinkovitost, očekivani napor (ulog), društveni utjecaj te olakšavajući uvjeti, a čiji učinci variraju ovisno o moderatorskim varijablama kao što su spol, godine, iskustvo i dobrovoljnost korištenja. ${ }^{31}$ Prema UTAUT-modelu jezgreni konstrukti (očekivana učinkovitost, očekivani napor, društveni utjecaj) utječu na bihevioralnu namjeru korištenja tehnologije, dok bihevioralna namjera korištenja te olakšavajući uvjeti određuju korištenje tehnologije. ${ }^{32}$ Model UTAUT jedan je od najtestiranijih teorijskih modela vrednovanja prihvaćanja i korištenja tehnologije te je razvijeno i mnogo modificiranih UTAUT-modela. Sami autori modela predložili su 2012. godine prošireni UTAUT2-mode ${ }^{33}$ u kojem su uvedeni novi konstrukti (hedonistička motivacija, cjenovna vrijednost te navika) u kontekstu potrošača. Cilj je teorijskog modela UTAUT objasniti interes korisnika za korištenje informacijskog sustava, odnosno objasniti razloge prihvaćanja tehnologije kod budućih korisnika. Autori teorijskog modela obrazlažu jezgrene konstrukte na sljedeći način ${ }^{34}$ : očekivana učinkovitost (engl. performance expectancy - PE) predstavlja uvjerenja osobe da će korištenje tehnologije pomoći u postizanju izvedbenih, radnih mogućnosti. Konstrukt očekivane učinkovitosti zamijenio je konstrukt percipirane korisnosti iz teorijskog mo-

\footnotetext{
30 Venkatesh, V.; M. G. Morris; G. B. Davis; F. D. Davis., Nav. dj., str. 425-478.

31 Usp. Williams, M. D.; P. R. Nripendra; Y. K. Dwivedi. Nav. dj. ; Usp. Krelja Kurelović, E. Prihvaćanje otvorenog pristupa znanstvenim informacijama i obrazovnim sadržajima u hrvatskoj akademskoj zajednici: doktorski rad. Zagreb: Filozofski fakultet Sveučilišta , 2017. Str. 97-98.

32 Usp. Venkatesh, V.; J. Y. L. Thong; X. Xu. Unified theory of acceptance and use of technology: a synthesis and the road ahead. // Journal of the Association for Information Systems 17, 5(2016), str. 329.

33 Usp. Venkatesh, V.; J. Y. L. Thong; X. Xu. Consumer acceptance and use of information technology: extending the Unified theory of acceptance and use of technology. // MIS Quarterly 36, 1(2012), 157-178.

34 Usp. Williams, M. D.; P. R. Nripendra; Y. K. Dwivedi. Nav. dj., str. 447-453.
} 
dela TAM. Očekivani napor (engl. effort expectancy - EE) jest razina prikladnosti korištenja informacijskog sustava, dok se društveni utjecaj (engl. social influence - SI) obrazlaže utjecajem radne okoline na korisnikovu namjeru da koristi sustav. Olakšavajući uvjeti (engl. facilitating condition - FC) odnose se na korisnička uvjerenja da je organizacijska i tehnička infrastruktura dostupna pri korištenju sustava. Korištenje (engl. use behaviour - UB) se definira kao intenzitet, odnosno frekvencija kojom korisnik koristi informacijsku tehnologiju.

Valja također naglasiti kako su područja analize i testiranja teorijskog UTAUT-modela mnogobrojna, pa tako i u području knjižničarstva. ${ }^{35}$ Teorijski model najčešće se koristi iz perspektive istraživanja motiva krajnjih korisnika informacijskih sustava, pa stoga Rabina i Walczyk ${ }^{36}$ ističu kako se knjižničare, nažalost, ne percipira kao korisnike, pa su istraživanja o primjeni informacijsko-komunikacijske tehnologije na skupini ispitanika knjižničara skoro pa zanemariva. Također, važno je napomenuti kako automatizacija, tj. primjena i korištenje tehnologije nemaju isti učinak na skupinu pomoćnih knjižničara i skupinu knjižničara na vodećim pozicijama, odnosno knjižničara menadžera. Horsfall ${ }^{37}$ je istražila utjecaj uvođenja automatizacije knjižničnog poslovanja ispitujući stavove visokoškolskih knjižničara o kvaliteti radnog okruženja, zadovoljstvu poslom, razini samouvjerenosti, stupnju morala i dr. Autorica ističe kako automatizacija ima veći utjecaj na knjižnično pomoćno osoblje negoli na same diplomirane knjižničare. Dok su knjižničari na vodećim pozicijama iskazivali zadovoljstvo automatizacijom, vidjevši u tome priliku za usvajanje novih znanja, oslobađanje od repetitivnih zadataka i usvajanje novih i zanimljivih poslovnih zadataka, pomoćni knjižničari iskazivali su osjećaj smanjenja radnog zadovoljstva, gubitak samouvjerenosti i stupnja morala te smanjenje kvalitete rada za koji su smatrali da je nakon automatizacije postao tehnički zahtjevniji i monotoniji. Horsfall također navodi zaključak kako zadovoljstvo uvođenja automatizacije knjižničnog poslovanja znatno opada kod pomoćnih knjižničara u odnosu na ispitivanja prije i poslije uvođenja automatizacije, dok se neznatno smanjenje očekivanja od procesa automatizacije kod knjižničara vezuje uz činjenicu da su sagledane ne samo prednosti već i neminovni nedostaci provedene automatizacije. Jantz ${ }^{38}$ također ističe velik značaj liderske uloge knjižničara menadžera u procesu uvođenja tehničkih inovacija u visokoš-

\footnotetext{
35 Usp. Weerasinghe, S.; M. Hindagolla. Technology acceptance model in the domains of LIS and education: a review of selected literature. // Library Philosophy an Practice (e-journal). 2017. [citirano: 2018-03-31]. Dostupno na: http://digitalcommons.unl.edu/libphilprac/1582.

36 Usp. Rabina, D. L.; D. J. Walczyk. Information professionals' attitude toward the adoption of innovations in everyday life. // Information Research 12, 4(2007), 1-12. [citirano: 2018-03-31]. Dostupno na: http://InformationR.net/ir/12-4/colis12.html.

37 Usp. Horsfall, J. The human impact of library automation. [citirano: 2018-03-31]. Dostupno na: http://web.simmons.edu/ chen/nit/NIT\%2792/195-hor.htm.

38 Usp. Jantz, R. C. Innovation in academic libraries: an analysis of university librarians' perspectives. // Library \& Information Science Research 34, (2012), 3-12.
} 
kolske knjižnice, što se smatra temeljnom pretpostavkom opstanka knjižnica u suvremenom društvu.

Na temelju istraživanja modela prihvaćanja novih tehnologija za učenje na daljinu na hrvatskim sveučilištima ${ }^{39}$, Badurina primjenjuje TAM-model te zaključuje kako konstrukt percipirane korisnosti ima veći utjecaj na korištenje i namjeru korištenja tehnologije u nastavi nego što to iskazuje percipirana lakoća korištenja. Zaključak se obrazlaže činjenicom da ispitanici imaju samo djelomičnu slobodu izbora korištenja sustava za e-učenje, a da se u velikoj mjeri radi o tehnologiji koju sudionici obrazovnog procesa moraju koristiti. Komplementarna istraživanja također nalazimo i u istraživanju stavova knjižničnog menadžmenta vezano uz prihvaćanje informacijskog knjižničnog sustava nove generacije $\mathrm{e}^{40}$ te $\mathrm{u}$ istraživanju prihvaćanja knjižničnog informacijskog sustava otvorenog koda kod visokoškolskih knjižničara u Maleziji. ${ }^{41}$

\section{Istraživanje}

Istraživanje je imalo za cilj analizirati u kojoj mjeri knjižnice integriranog knjižničnog sustava Aleph koriste i prihvaćaju zajednički integrirani knjižnični program, utvrditi postoje li i, ako postoje, koji čimbenici utječu na njihovu motivaciju, tj. namjeru da nastave nadalje koristiti integrirani knjižnični sustav Aleph te možemo li u okviru integriranog knjižničnog sustava Aleph utvrditi okvir, tj. dimenzije uspješnosti koje bitno utječu na procjenu njegove uspješnosti.

Istraživanje bi trebalo ponuditi odgovore na sljedeća istraživačka pitanja:

P 1. Koriste li knjižnice integriranog knjižničnog sustava Aleph implementirani integrirani knjižnični program te u kojoj mjeri prihvaćaju integrirani knjižnični sustav Aleph?

Mjerenje korištenja informacijskog sustava predstavlja nezavisnu varijablu koju je moguće iskazati kvantitativnim pokazateljima izravnim uvidom u tablice sustava. Međutim istraživanje prihvaćanja knjižničnog informacijskog sustava Aleph usmjereno je na analizu zavisne varijable koja ovisi o vrijednostima korištenja sustava i utjecaju sustava na korisničko ponašanje te na zadovoljstvo informacijskim sustavom. Takvo istraživanje nadilazi mogućnosti izravnog uvida u kvantitativne podatke sustava te mu je potrebno metodološki drukčije pristupiti.

39 Usp. Badurina, B. Model prihvaćanja novih tehnologija za učenje na daljinu na hrvatskim sveučilištima: doktorska disertacija. Zagreb: Filozofski fakultet Sveučilišta, 2010.

40 Usp. Mfengu, A. Y. Analysis of the approaches of senior management teams towards adoption of next generation library management systems: a case study of Cape Library consortium institutions. Cape Town: University, 2014.

${ }^{41}$ Usp. Mohideen, Z. A. Librarian's acceptance of open source library information system using the OSIS-UTAUT model: doctoral thesis. Kuala Lumpur: Faculty of Computer Science and Information Technology, Unversity of Malaya, 2017. 
Već smo ranije naglasili da se korištenje informacijskog sustava ne treba poistovjetiti s njegovim prihvaćanjem, a posebice je ta razlika naglašena kad se donekle radi o obvezi korištenja određenog informacijskog sustava.

P 2. Koji čimbenici utječu na namjeru integriranih knjižnica da se nastave koristiti integriranim knjižničnim sustavom Aleph?

Namjera nastavka korištenja integriranog knjižničnog sustava također predstavlja zavisnu varijablu, koja u odnosu na specifičnosti promatranog integriranog knjižničnog sustava Aleph može ovisiti o specifičnim moderatorskim varijablama, kao što su vrsta knjižnice, radni status ispitanika (pomoćni knjižničar, diplomirani knjižničar, voditelj knjižnice i dr.), spolna i dobna obilježja ispitanika, prethodno iskustvo, stavovi okoline i suradnika i sl. Istraživanje uzročnih varijabli koje najizravnije utječu na namjeru daljnjeg korištenja integriranog knjižničnog sustava Aleph pomoći će u planiranju daljnjih aktivnosti na razvoju sustava.

P 3. Može li se na temelju rezultata prethodnih dvaju istraživačkih pitanja definirati okvir za procjenu uspješnosti, tj. možemo li utvrditi mjeru uspješnosti integriranog knjižničnog sustava Aleph?

Predloženih šest dimenzija procjene uspješnosti informacijskih sustava prema D\&M-modelu uspješnosti ${ }^{42}$, kvaliteta sustava, kvaliteta informacije, kvaliteta usluge, korištenje (namjera korištenja) sustava, korisničko zadovoljstvo i dobit, predstavljaju konsolidirani i višedimenzionalni pristup mjerenju elemenata, tj. međuzavisnih varijabli koje utječu na cjelokupnu procjenu uspješnosti informacijskog sustava. Istraživanje bi trebalo utvrditi koji su atributi i dimenzije navedenog modela primjenjivi za procjenu uspješnosti integriranog knjižničnog sustava Aleph te trebaju li se istaknuti neke njegove specifičnosti koje bi imale presudan utjecaj na procjenu uspješnosti.

\subsection{Metodologija}

Metodom deskriptivne statistike analizirani su kvantitativni podaci o integriranom knjižničnom sustavu Aleph koji su prikupljeni temeljem SQL-upita (engl. Structured Query Language) na baze integriranog knjižničnog sustava ili izravnim uvidom u podatke iz programskih tablica. Na taj način prikupljeni su kvantitativni pokazatelji o veličini, značajkama i aktivnostima sustava koji se bilježe automatizirano u programske i izvještajne tablice sustava.

S ciljem analize korisničkog iskustva vezanog uz prihvaćanje i korištenje integriranog knjižničnog sustava Aleph testirana je primjena metodologije modificiranog UTAUT-modela. Za potrebe UTAUT-modela korišteni su podaci prikupljeni putem ankete „Funkcionalno testiranje Alepha u odnosu na razinu korištenja pro-

42 Usp. DeLone, W. H.; E. R. McLean. Nav. dj., 2003. 
gramskih modula te zadovoljstvo korištenja sustava Buki ${ }^{\text {‘43 }}$, koja je provedena u razdoblju od ožujka do travnja 2016. godine na uzorku od 43 voditelja knjižnica iz sustava visokog obrazovanja i znanosti Republike Hrvatske u koje je implementiran integrirani knjižnični program Aleph.

Anketni upitnik sastoji se od više od 50 pitanja strukturiranih u četiri cjeline. Sam upitnik zbog svoje veličine nije mogao biti prilogom ovog rada. Pitanja u prvoj cjelini namijenjena su prikupljanju podataka o knjižnici i korisnicima sustava. Pitanja iz druge cjeline tražila su od ispitanika da označe stupanj korištenja navedenih implementiranih funkcionalnosti programskih modula izborom jednog od ponuđenih odgovora: DA, NE, PLANIRAM U BUDUĆNOSTI, NE ZNAM i POTREBNO UNAPRIJEDITI. Potom se primjenom Likertove skale u rasponu vrijednosti od 1 do $5-1$ (nedovoljno), 2 (dovoljno), 3 (dobro), 4 (vrlo dobro) te 5 (izvrsno) - od ispitanika tražilo da ocijene zadovoljstvo korištenja pojedinačnim programskim modulima. $U$ formi otvorenog pitanja ispitanici su imali mogućnost upisati napomenu za svaku pojedinačnu funkcionalnost knjižničnog programa. Pitanja treće cjeline od ispitanika su tražila ocjenu zadovoljstva organizacijskom podrškom te programom edukacije koji su namijenjeni korisnicima integriranog knjižničnog sustava, također primjenom Likertove skale od 1 (nedovoljno) do 5 (izvrsno). Završna cjelina sastoji se od otvorenog pitanja namijenjenog prikupljanju dodatnih prijedloga ispitanika vezano uz funkcionalno unapređenje rada u sustavu te usluga nacionalnog integriranog knjižničnog sustava.

Kako anketni upitnik nije unaprijed dizajniran sukladno UTAUT-modelu, poslužili smo se dijelom upitnika koji je prikupio odgovore voditelja knjižnica vezano uz korištenje programskih modula, namjeru korištenja programskih modula u budućnosti, ocjenu kvalitete sustava, zadovoljstvo informacijskim sustavom te percepciju lakoće korištenja sustava. Iz navedenih segmenata odgovora oblikovani su sljedeći konstrukti vrednovanja:

Percipirana učinkovitost $(P U)$ - Podaci koje ubrajamo u kategoriju percipirana učinkovitost sustava odnose se na broj funkcionalnosti pojedinog modula koje su ispitanici odlučili koristiti u okviru ukupnog broja implementiranih funkcionalnosti. Interval učinkovitosti iskazujemo na Likertovoj skali od 1 do 3, pri čemu 1 označava neslaganje, 2 djelomično slaganje, a 3 potpuno slaganje ispitanika $\mathrm{s}$ pretpostavkom o učinkovitosti programskih modula.

Intencija korištenja (IK) - Podaci koje pripisujemo kao namjeru ili intenciju korištenja iskazani su zbrojem odgovora „PLANIRAM U BUDUĆNOSTI“ prikupljenih u drugoj cjelini anketnog upitnika. Te se vrijednosti odnose na ukupnost funkcionalnosti pojedinih modula koje ispitanici tek planiraju koristiti.

Percepcija lakoće korištenja (PLK) - Na vrijednost kojom izražavamo percepciju lakoće korištenja integriranog knjižničnog programa utječe razlika broja

43 Preliminarni rezultati ankete zbirno su dostupni na adresi http://iks.nks.hr/fta. 
odgovora „NE ZNAM“ i „POTREBNO UNAPRIJEDITI“ unutar ukupnog broja mogućih odgovora. Pretpostavljamo da ispitanici koji za korištenje pojedine funkcionalnosti nisu znali odgovoriti koriste li ju ili su odgovorili da funkcionalnost zahtijeva unapređenje utječu na ukupnu percepciju lakoće korištenja sustava.

Percepcija kvalitete sustava (PKS) - Percepcija kvalitete sustava izražena je odabranom vrijednošću s Likertove skale u vrijednostima od 1 (ne laganje) do 3 (potpuno slaganje), pri čemu ocjene $0-1$ imaju vrijednost neslaganja, 2-3 djelomičnog slaganja, a vrijednosti 4 i 5 potpunog slaganja s iskazom o kvaliteti sustava. Prema UTAUT-modelu taj konstrukt nalazio bi svoj parnjak u konstruktu Društveni utjecaj (SE).

Zadovoljstvo IS (ZIS) - Vrijednost zadovoljstva knjižničnim informacijskim sustavom izražena je ukupnim brojem odabranih vrijednosti Likertove skale od 1 do 3 vezano uz ocjenu zadovoljstva organizacijskom podrškom te programima edukacije. Konstrukt ZSI sukladan je konstruktu Olakšavajući uvjeti izvornog UTAUT-modela.

Prikupljeni podaci analizirani su faktorskom analizom, izražena je vrijednost njihova prosječnog odstupanja (standardna devijacija) i prosječna vrijednost te je izračunat Pearsonov koeficijent korelacije $\left(\mathrm{r}^{2}\right)$. S obzirom na to da su se za potrebe istraživanja koristili rezultati prikupljeni online anketom koja primarno nije bila dizajnirana sukladno UTAUT-metodologiji te da je anketiranje izvršeno na relativno malom uzorku ispitanika $(\mathrm{N}=27)$, validitet proračuna potvrđen je koeficijentima pouzdanosti Cronbach's alfa te Spearman-Brown, koji su u pozitivnim granicama. Pri obradi podataka metodom deskriptivne statistike te izračuna Pearsonova koeficijenta korelacije i vizualizacije podataka korišteni su programi $M S$ Excel, $R$ te proračunski predložak za izračun testa pouzdanosti. ${ }^{44}$

\subsection{Značajke ispitnog uzorka}

Anketnim upitnikom propitani su voditelji knjižnica iz sustava znanosti i visokog obrazovanja Republike Hrvatske koji u svom poslovanju koriste integrirani knjižnični program Aleph. Istraživanje je usmjereno na voditelje knjižnica kao grupu ispitanika kod koje je izražena ekstrinzična motivacija prihvaćanja tehnologije (povećanje kvalitete rada, napredak u karijeri i sl.) i imanentna sklonost uvođenju inovacija ${ }^{45}$ te su u najvećoj mjeri umanjena eventualna ograničenja koja bi mogla negativno utjecati na motivaciju. ${ }^{46}$

\footnotetext{
44 Excelov predložak za izračun testa pouzdanosti dostupan je na izvoru Siegle, D. Instrument reliability. // University of Connecticut. [citirano:2018-06-08]. Dostupno na: https://researchbasics.education.uconn.edu/instrument_reliability/.

45 Usp. Jantz, R. C. Nav. dj., str. 3.

46 Usp. Horsfall, J. Nav. dj., [citirano: 2018-03-31]. Dostupno na: http://web.simmons.edu/ chen/nit/NIT\%2792/195-hor.htm.
} 
Premda se korištenje integriranog knjižničnog sustava po njegovoj implementaciji u visokoškolskim knjižnicama može smatrati obveznim, knjižnicama je ostavljeno na izbor u kojoj će se mjeri i obimu koristiti programskim paketom. Premda su projektom automatizacije knjižničnih poslovanja hrvatskih visokoškolskih knjižnica implementirani i raspoloživi svi programski moduli (modul katalogizacije, modul nabave, modul cirkulacije, kontrola pristizanja serijskih publikacija, izrada izvještaja i biltena te WebPAC), ostaje za analizirati u kojoj su se mjeri voditelji knjižnica odlučili koristiti programskim paketom te koje su im namjere vezano uz njegovu daljnju implementaciju i punu automatizaciju njihova knjižničnog poslovanja.

U odnosu na izbor mogućih moderatorskih varijabli (spol, godine, iskustvo, dobrovoljnost korištenja, cijena, hedonistički učinak i sl.), te varijable neće biti obuhvaćene istraživanjem jer smatramo da u našem primjeru nemaju odlučujući utjecaj.

\section{Rezultati}

\subsection{Kvantitativni pokazatelji integriranog knjižničnog sustava Aleph}

Kvantitativni pokazatelji o veličini i značajkama sustava, koji se bilježe automatizirano u programske i izvještajne tablice sustava, prikupljeni su 10. studenoga 2017. godine metodom SQL-upita na baze i programske datoteke sustava. Poradi utvrđivanja uzorka istraživanja u tablici 1 prikazani su kvantitativni pokazatelji o strukturi, veličini i funkcionalnim značajkama integriranog knjižničnog sustava Aleph komparativno za sustav NSK i sustav ZAG. Sustav NSK obuhvaća podatke programskih baza automatiziranog knjižničnog poslovanja Nacionalne i sveučilišne knjižnice u Zagrebu (NSK01, NSK50, NSK60, NSK10), a sustav ZAG podatke iz programskih baza (ZAG01, ZAG50, ZAG60) koje koriste ostale integrirane knjižnice (sveučilišna, visokoškolske, veleučilišne i specijalne), i to neovisno o njihovoj geografskoj lokaciji. U tablici 1 aktivnosti obaju sustava izražene su pokazateljima o ukupnom broju izrađenih bibliografskih zapisa (BIB), ukupnom broju zapisa o primjerku (ITEM), ukupnom broju zapisa o posjedovanju (HOL), ukupnom broju korisnika, ukupnom broju izrađenih normativnih zapisa te ukupnom broju aktivnih radnih profila, tj. broju djelatnika koji rade u programu Aleph.

Tablica 1. Kvantitativni podaci o strukturi, veličini i funkcionalnim značajkama integriranog knjižničnog sustava Aleph komparativno za sustav NSK i sustav ZAG na dan 10. studenoga 2017.

\begin{tabular}{|l|c|c|c|}
\hline ZNAČAJKE SUSTAVA & NSK & ZAG & UKUPNO \\
\hline Naziv značajke & N1 & N2 & $\Sigma($ N1, N2) \\
\hline Bibliografski zapisi & 966.981 & 491.921 & $\mathbf{1 . 4 5 8 . 9 0 2}$ \\
\hline
\end{tabular}




\begin{tabular}{|l|r|r|r|}
\hline ZNAČAJKE SUSTAVA & \multicolumn{1}{|c|}{ NSK } & \multicolumn{1}{|c|}{ ZAG } & \multicolumn{1}{c|}{ UKUPNO } \\
\hline Podaci o korisnicima & 15.970 & 10.941 & $\mathbf{2 6 . 9 1 1}$ \\
\hline Normativni zapis & 558.647 & -47 & $\mathbf{5 5 8 . 6 4 7}$ \\
\hline Zapisi o posjedovanju & 873.443 & 121.435 & $\mathbf{9 9 4 . 8 7 8}$ \\
\hline Zapisi o primjerku & 704.733 & 223.015 & $\mathbf{9 2 7 . 7 4 8}$ \\
\hline Aktivni radni profili & 217 & 57 & $\mathbf{2 7 4}$ \\
\hline Broj bibliografskih baza & 1 & 1 & $\mathbf{2}$ \\
\hline Broj normativnih baza & 1 & - & $\mathbf{1}$ \\
\hline Broj knjižnica & 1 & 42 & $\mathbf{4 3}$ \\
& NSK & $\begin{array}{r}\text { 1 sveučilišna } \\
\text { 11 specijalnih }\end{array}$ & \\
\hline
\end{tabular}

Za potrebe istraživanja dodatno je izlučen uzorak od 42 knjižnice iz sustava znanosti i visokog obrazovanja koje su u tablici 1 predstavljene skupom ZAG. SQL-upiti oblikovani su za prikupljanje podataka iz sistemskih tablica sustava ZAG za vremenski obuhvat podataka od 2011. do 2017. godine. SQL-upitima nad podacima sustava ZAG prikupljeni su podaci o ukupnom broju izrađenih bibliografskih zapisa, ukupnom broju zapisa o korisnicima, godišnjem broju zapisa o primjerku i zapisa o posjedovanju, broju posudbi građe te ukupnom broju aktivnih radnih profila. Metodom deskriptivne statistike analizirani su sistemski podaci sustava ZAG iskazani u tablici $2 \mathrm{u}$ vrijednostima medijana i prosječne vrijednosti.

Tablica 2. Sistemski podaci sustava ZAG za razdoblje od 2011. do 2017. izraženi u medijanu i prosječnoj vrijednosti

\begin{tabular}{|l|l|l|l|l|l|l|l|r|r|}
\hline $\begin{array}{l}\text { SUSTAV } \\
\text { ZAG }\end{array}$ & $\mathbf{2 0 1 1}$ & $\mathbf{2 0 1 2}$ & $\mathbf{2 0 1 3}$ & $\mathbf{2 0 1 4}$ & $\mathbf{2 0 1 5}$ & $\mathbf{2 0 1 6}$ & $\mathbf{2 0 1 7}$ & $\begin{array}{c}\text { Me- } \\
\text { dijan }\end{array}$ & Prosjek \\
\hline $\begin{array}{l}\text { Bibliograf- } \\
\text { ski zapisi }\end{array}$ & 32.485 & 27.584 & 19.223 & 18.288 & 16.694 & 12.489 & 12.217 & 18.288 & $19.854,28$ \\
\hline $\begin{array}{l}\text { Podaci o } \\
\text { korisnicima }\end{array}$ & 23.033 & 13.277 & 23.083 & 10.073 & 11.867 & 9.450 & 10.941 & 13.277 & 14.532 \\
\hline $\begin{array}{l}\text { Zapisi o po- } \\
\text { sjedovanju }\end{array}$ & 7.663 & 19.231 & 25.577 & 19.120 & 17.221 & 13.136 & 12.750 & 17.221 & $16.385,42$ \\
\hline $\begin{array}{l}\text { Zapisi o } \\
\text { primjerku }\end{array}$ & 12.917 & 28.646 & 40.040 & 43.645 & 37.293 & 28.583 & 16.171 & 37.293 & $29.613,57$ \\
\hline
\end{tabular}

${ }^{47}$ Knjižnice sustava ZAG rade u kooperativnom programu normativnog nadzora te sudjeluju $u$ izradi i dopuni autoriziranih odrednica imena u jedinstvenoj normativnoj bazi. 


\begin{tabular}{|l|r|r|r|r|r|r|r|r|r|}
\hline $\begin{array}{l}\text { SUSTAV } \\
\text { ZAG }\end{array}$ & $\mathbf{2 0 1 1}$ & $\mathbf{2 0 1 2}$ & $\mathbf{2 0 1 3}$ & $\mathbf{2 0 1 4}$ & $\mathbf{2 0 1 5}$ & $\mathbf{2 0 1 6}$ & $\mathbf{2 0 1 7}$ & $\begin{array}{c}\text { Me- } \\
\text { dijan }\end{array}$ & Prosjek \\
\hline $\begin{array}{l}\text { Posudba } \\
\text { građe }\end{array}$ & 8.220 & 9.966 & 15.819 & 18.824 & 23.364 & 28.130 & 28.748 & 18.824 & 19.010 \\
\hline $\begin{array}{l}\text { Aktivni } \\
\text { radni profili }\end{array}$ & 43 & 51 & 56 & 61 & 59 & 56 & 57 & 56 & 54,71 \\
\hline
\end{tabular}

Prema podacima o broju novoizrađenih bibliografskih zapisa u sustavu ZAG, prikazanim u tablici 2, primjećuje se da se broj bibliografskih zapisa, nakon početne velike produkcije, nastavlja zadržavati nešto ispod ukupnog prosječnog broja izrađenih bibliografskih zapisa $(19.854,28)$.

Usporedimo li kretanje broja radnih profila u integriranom knjižničnom programu prema godinama, uočava se da, premda je broj radnih profila kontinuirano iznad prosjeka $(\mathrm{N}=54.71)$, taj pokazatelj nije u korelaciji s brojem novoizrađenih bibliografskih zapisa (slika 1).

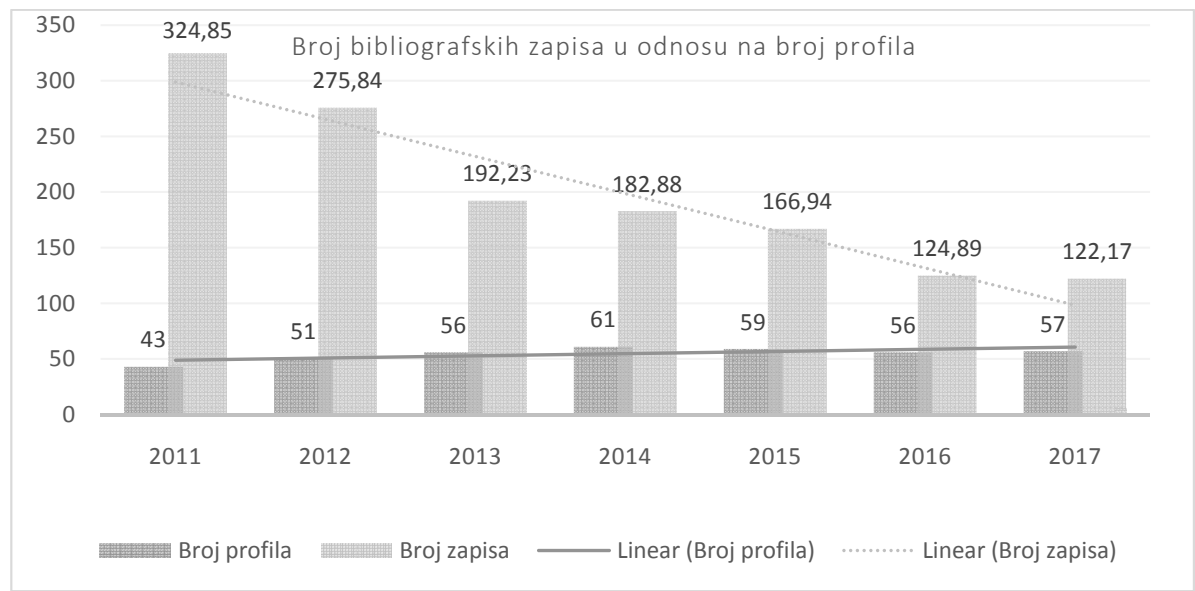

Slika 1. Usporedni prikaz broja radnih profila u programskom paketu i broja izrađenih bibliografskih zapisa godišnje uz liniju trenda broja novoizrađenih bibliografskih zapisa

Vidljivo je da sustav ZAG ulaže u razvoj ljudskih resursa koji rade u integriranom knjižničnom sustavu Aleph, no valja analizirati u koje se segmente sustava odlučilo ulagati, ako to nije modul katalogizacije, tj. u svrhu bibliografske kontrole.

Analizirat ćemo stupanj korelacije povećanja broja radnih profila u integriranom knjižničnom sustavu Aleph s brojem zapisa o posjedovanju i zapisa o primjerku (slika 2). 


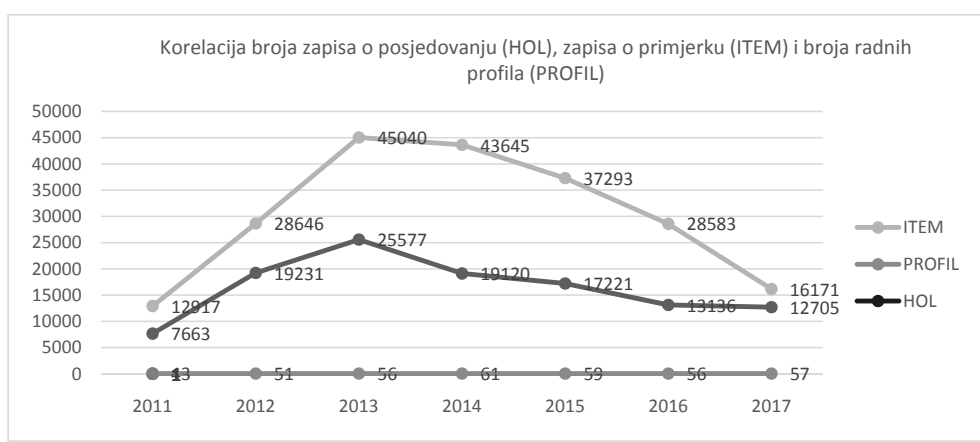

Slika 2. Korelacija broja radnih profila (PROFIL) i ukupnog broja zapisa o posjedovanju (HOL) i zapisa o primjerku (ITEM)

Uočava se korelacija između linija trendova razvoja ljudskih resursa koji aktivno rade u sustavu te kretanja ukupnog broja izrađenih zapisa o primjerku i zapisa o posjedovanju.

Ostaje za analizirati jesu li ulaganja u povećanje korištenja sustava koja se uočavaju u trendu godišnjeg povećanja broja zapisa o primjerku i zapisa o posjedovanju rezultirala i većim brojem korisnika knjižnice ili povećanjem usluga knjižnice samim korisnicima.

S tim ciljem usporedit ćemo linije eksponencije godišnjeg broja korisnika i ukupnog broja posudbe građe. Slika 3 prikazuje kako se ne može uočiti korelacija između povećanja broja korisnika, koji je relativno stabilan, i ukupnog broja posudbi, koji je svake godine sve veći. Razložno je obrazložiti stalan broj korisnika visokoškolskih knjižnica činjenicom da broj korisnika knjižnice prati broj ukupno upisanih studenata na pojedinu visokoškolsku ustanovu. Međutim povećanje broja posudbi građe $\mathrm{u}$ odnosu na isti broj korisnika govori u prilog povećanju razine usluge same knjižnice.

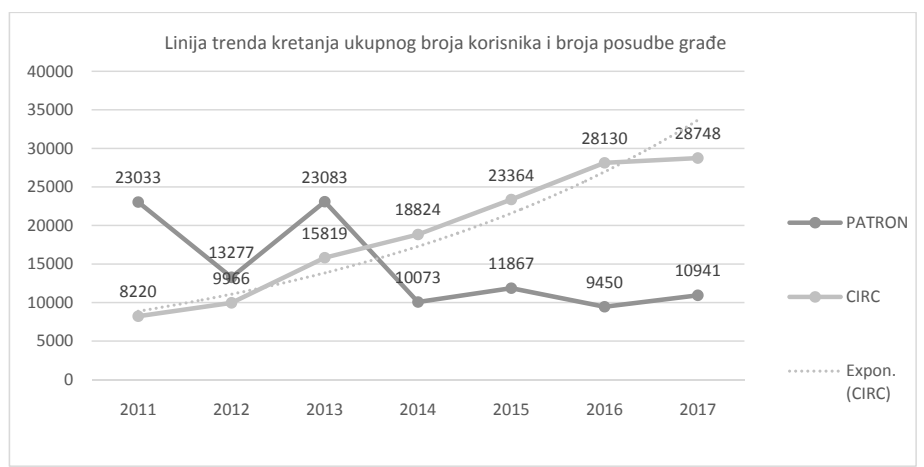

Slika 3. Broj korisnika knjižnice (PATRON) i ukupan broj posudbe građe (CIRC) naznačen uz liniju trenda kretanja broja posudbi građe (Eksp. (CIRC)) 
Uvidom u ovu analizu korištenja sustava temeljenu na sistemskom pristupu može se zaključiti da je sustav ZAG relativno dinamičan sustav u kojem je zabilježeno povećanje broja radno aktivnih profila. Kako se motivacija za korištenje integriranog knjižničnog sustava Aleph ne može tražiti u spektru intrinzičnih ili dobrovoljnih varijabli samih knjižničara, povećanje broja radnih profila korelira s povećanjem broja zapisa o primjerku i zapisa o posjedovanju. Sukladno tomu, može se zaključiti da se nakon inicijalne automatizacije poslovanja knjižnica, pri čemu je vidljiv porast broja bibliografskih zapisa, sustav nastavljao razvijati u području drugih programskih modula, prije svega cirkulacije. Ulaganje u automatizaciju i daljnji razvoj automatizacije svih razina knjižničnog poslovanja rezultirao je povećanjem broja posudbi građe, koji bilježi konstantno izražen uzlazni trend kretanja. Usporedni prikaz linija kretanja automatiziranih knjižničnih procesa u sustavu ZAG prikazan je na slici 4.

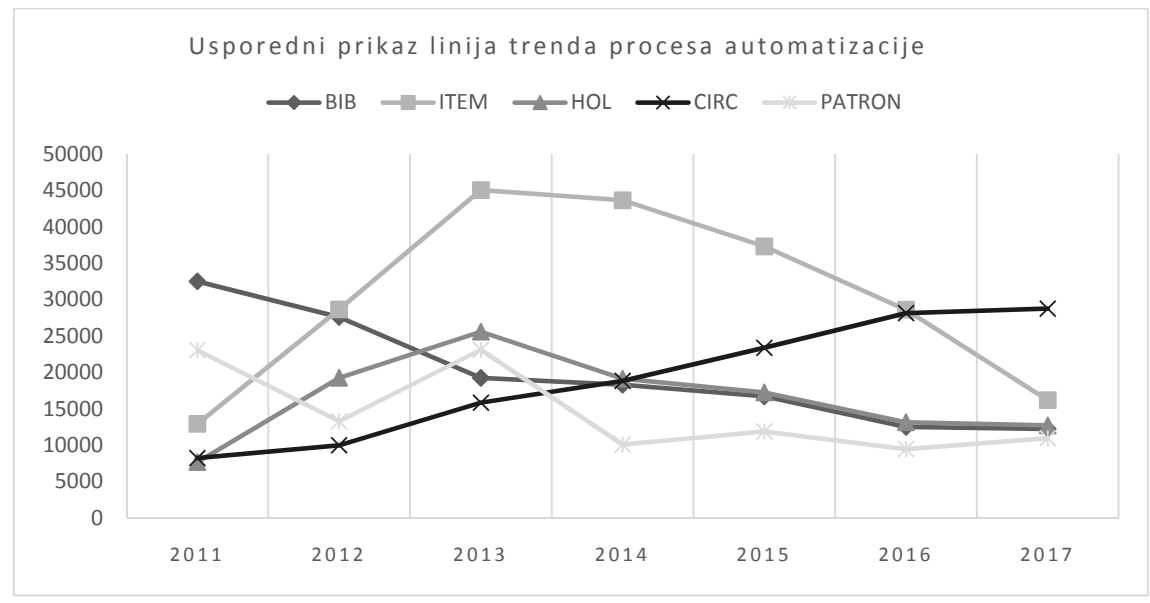

Slika 4. Usporedne linije kretanja broja bibliografskih zapisa (BIB), zapisa o primjerku (ITEM), zapisa o posjedovanju (HOL), zapisa o posudbi građe (CIRC) te broja korisnika za sustav (PATRON) ZAG

Kvantitativni podaci dobiveni iz sistemskih tablica integriranog knjižničnog sustava Aleph pokazali su, na temelju sistemskog pristupa analize korištenja tehnologije, kako je automatizacija knjižničnih poslovanja rezultirala povećanjem razine usluge integriranih knjižnica.

Ono što nije vidljivo iz sistemskog pristupa jesu motivacijske varijable koje utječu na odluku knjižničara da nastave koristiti ili dalje ulažu u proces automatizacije svojih poslovanja, kao ni specifične dimenzije koje utječu na povećanje uspješnosti implementiranog informacijskog sustava. 


\subsection{Metoda predviđanja namjere korištenja knjižničnog informacij- skog sustava}

S ciljem predikcije čimbenika, odnosno bihevioralnih motiva koji će utjecati na voditelje knjižnica da nastave prihvaćati i koristiti integrirani knjižnični program Aleph, testirat ćemo primjenu metodologije prethodno opisanog modificiranog UTAUT-modela.

U tu svrhu poslužit ćemo se podacima prikupljenim anketnim istraživanjem nad ispitnim uzorkom koji čine voditelji visokoškolskih knjižnica te voditelji knjižnica znanstvenih instituta, a čija su poslovanja automatizirana implementacijom integriranog knjižničnog programa Aleph te su korisnici integriranog knjižničnog sustava Aleph. Na anketu je odgovorilo 27 od ukupno 42 voditelja knjižnice, odnosno njih $64 \%$. U odnosu na stratifikaciju prema vrsti visokoškolskih knjižnica, odgovore na anketu ispunilo je 6 specijalnih knjižnica, 1 sveučilišna, 2 veleučilišne i 18 fakultetskih knjižnica. Značajke i stratifikacija uzorka prema spolu i vrsti knjižnice ispitanika te planu proširenja radno aktivnih profila u sustavu iskazane su u tablici 3. Kako ispitanici većinom imaju iste značajke, te ćemo moderatorske varijable isključiti iz modificiranog UTAUT-modela.

Tablica 3. Značajke i stratifikacija ispitanika prema vrsti knjižnice, spolu ispitanika te planu proširenja radnih profila

\begin{tabular}{|l|c|c|c|c|c|}
\hline $\begin{array}{l}\text { Stratifikacija ispitanika prema } \\
\text { vrsti visokoškolske knjižnice }\end{array}$ & N & \multicolumn{2}{|c|}{ Spol } & \multicolumn{2}{c|}{$\begin{array}{c}\text { Plan proširenja radnih } \\
\text { profila }\end{array}$} \\
\hline Vrsta visokoškolske knjižnice & & Ženski & Muški & DA & NE \\
\hline Sveučilišne & 1 & 0 & 1 & 0 & 1 \\
\hline Veleučilišne & 2 & 0 & 2 & 0 & 2 \\
\hline Specijalne & 6 & 6 & 0 & 0 & 6 \\
\hline Fakultetske & 18 & 17 & 1 & 3 & 15 \\
\hline Ukupno & 27 & 23 & 4 & 3 & 24 \\
\hline
\end{tabular}

Rezultati ispitivanja korištenja programskih modula prikazani u tablici 4 pokazuju da sve ispitane knjižnice koriste modul katalogizacije $(\mathrm{N}=27)$. Također, velik broj knjižnica $(\mathrm{N}=20)$ planira u budućnosti proširiti korištenje modula katalogizacije u segmentu nekih dodatnih funkcionalnosti. Zadovoljstvo modulom katalogizacije knjižnice izražavaju prosječnom ocjenom 3.5. Najmanje knjižnica koristi modul nabave $(\mathrm{N}=5)$, pa ne čudi što je i zadovoljstvo modulom nabave naj- 
lošije ocijenjeno, prosječnom ocjenom 2.9. Svega sedam $(\mathrm{N}=7)$ knjižnica planira u budućnosti koristiti nekih od segmenata modula nabave. Neke od funkcionalnosti modula cirkulacije koristi 13 knjižnica, a funkcionalnosti modula cirkulacije u budućnosti planira koristiti njih još 17 . Zadovoljstvo modulom cirkulacije knjižnice ocjenjuju prosječnom ocjenom 3.2.

Tablica 4. Pokazatelji korištenja i namjere korištenja integriranog knjižničnog sustava Aleph te ocjena zadovoljstva korištenjem programskim modulima i uslugama

\begin{tabular}{|l|c|c|c|c|c|}
\hline \multirow{2}{*}{ Elementi sustava } & \multicolumn{2}{|c|}{$\begin{array}{c}\text { Broj knjižnica } \\
\text { koje koriste } \\
\text { modul }\end{array}$} & \multicolumn{2}{|c|}{$\begin{array}{c}\text { Planira dodatno } \\
\text { koristiti u buduć- } \\
\text { nosti }\end{array}$} & $\begin{array}{c}\text { Ocjena zadovolj- } \\
\text { stva programskim } \\
\text { modulom }\end{array}$ \\
\cline { 2 - 6 } & $\mathbf{N}$ & $\mathbf{\%}$ & $\mathbf{N}$ & $\mathbf{\%}$ & \\
\hline $\begin{array}{l}\text { Funkcionalnosti modula } \\
\text { katalogizacije }\end{array}$ & 27 & 100 & 20 & 71 & 3.5 \\
\hline $\begin{array}{l}\text { Funkcionalnosti modula } \\
\text { nabave }\end{array}$ & 5 & 18 & 7 & 25 & 2.9 \\
\hline $\begin{array}{l}\text { Funkcionalnosti modula } \\
\text { cirkulacije }\end{array}$ & 13 & 46 & 17 & 60 & 3.2 \\
\hline WebPAC & 27 & 100 & 8 & 30 & 3.2 \\
\hline
\end{tabular}

Anketom je ispitano mišljenje voditelja knjižnica vezano uz zadovoljstvo korištenja knjižničnog informacijskog sustava Aleph u cjelini ostalih elemenata sustava. Voditelji su na Likertovoj skali vrijednostima od 1 (nedovoljno) do 5 (izvrsno) ocijenili stupanj zadovoljstva pojedinim elementima knjižničnog informacijskog sustava Aleph. Rezultati su prikazani u tablici 5.

Tablica 5. Zadovoljstvo korištenjem elemenata knjižničnog informacijskog sustava Aleph prema mišljenju voditelja knjižnica

\begin{tabular}{|l|c|c|c|c|c|c|}
\hline \multicolumn{1}{|c|}{ Elementi sustava / Ocjena } & $\mathbf{1}$ & $\mathbf{2}$ & $\mathbf{3}$ & $\mathbf{4}$ & $\mathbf{5}$ & Prosjek \\
\hline Pravno utvrđenje sustava & - & 2 & 11 & 8 & - & 3.3 \\
\hline Komunikacijski aspekt sustava & - & 6 & 4 & 11 & 6 & 3.6 \\
\hline $\begin{array}{l}\text { Kvaliteta i dostupnost uputa za rad i } \\
\text { priručnika }\end{array}$ & - & 2 & 4 & 17 & 4 & 3.9 \\
\hline Sustav za podršku & - & 1 & 6 & 10 & 10 & 4.1 \\
\hline
\end{tabular}




\begin{tabular}{|l|c|c|c|c|c|c|}
\hline \multicolumn{1}{|c|}{ Elementi sustava / Ocjena } & $\mathbf{1}$ & $\mathbf{2}$ & $\mathbf{3}$ & $\mathbf{4}$ & $\mathbf{5}$ & Prosjek \\
\hline Mrežni portal IKS ${ }^{48}$ & 1 & 3 & 3 & 15 & 4 & 3.7 \\
\hline Redaktorski nadzor & - & 3 & 8 & 8 & 3 & 3.5 \\
\hline Organizacija edukacije za sustav & 7 & 2 & 4 & 9 & 3 & 3 \\
\hline $\begin{array}{l}\text { Program edukacije: Funkcionalni rad u } \\
\text { modulu nabava }\end{array}$ & - & 2 & 4 & 11 & 1 & 3.6 \\
\hline $\begin{array}{l}\text { Program edukacije: Funkcionalni rad u } \\
\text { modulu katalogizacija }\end{array}$ & - & 2 & 3 & 17 & 2 & 3.8 \\
\hline $\begin{array}{l}\text { Program edukacije: Pretraživanje baza i } \\
\text { preuzimanje zapisa }\end{array}$ & - & 2 & 3 & 15 & 2 & 3.8 \\
\hline $\begin{array}{l}\text { Program edukacije: Funkcionalni rad u } \\
\text { modulu cirkulacija }\end{array}$ & - & 2 & 4 & 10 & 4 & 3.8 \\
\hline $\begin{array}{l}\text { Program edukacije: Servisi u modulu } \\
\text { cirkulacija }\end{array}$ & - & 1 & 4 & 10 & 2 & 3.8 \\
\hline $\begin{array}{l}\text { Program edukacije: Normativna baza } \\
\text { NSK }\end{array}$ & - & 2 & 5 & 12 & 2 & 3.7 \\
\hline
\end{tabular}

Iz anketnih pitanja oblikovali smo pet jezgrenih konstrukata prema UTAUT-modelu: PU (percepcija učinkovitost), IK (intencija korištenja), PLK (percepcija lakoće korištenja), PKS (percepcija kvalitete sustava) te ZS (zadovoljstvo sustavom). U tablici 6 iskazani su stavovi ispitanika o izvedenim pretpostavkama, uz naznačene vrijednosti medijana, standardne devijacije te koeficijenata pouzdanosti. Kako bismo utvrdili postoji li povezanost ili korelacija između jezgrenih konstrukata i konstrukta Intencija korištenja, izračunali smo Pearsonov koeficijent korelacije svakog konstrukta u odnosu na konstrukt Intencije korištenja. Dobiveni korelacijski koeficijenti naznačeni su na modificiranom UTAUT-modelu integriranog knjižničnog sustava Aleph (slika 5). Pearsonov koeficijent korelacije koristi se za intervalne vrijednosti, koje prikazujemo točkastim dijagramom (funkcijom scatterplot) uz izražen Pearsonov koeficijent $\mathrm{r}^{2}$ te liniju trenda (slika 6 i slika 7).

${ }^{48}$ Mrežni portal Integrirani knjižnični sustav - IKS. [citirano: 2018-05-31]. Dostupno na: http:// iks.nsk.hr. 
Tablica 6. Stavovi ispitanika prema izvedenim pretpostavkama

\begin{tabular}{|c|c|c|c|c|c|c|c|c|c|}
\hline & \multicolumn{2}{|c|}{$\begin{array}{l}\text { NE SLA- } \\
\text { ŽE SE }\end{array}$} & \multicolumn{2}{|c|}{$\begin{array}{l}\text { DJELO- } \\
\text { MIČNO } \\
\text { SE SLAŽE }\end{array}$} & \multicolumn{2}{|c|}{$\begin{array}{c}\text { U POT- } \\
\text { PUNOSTI } \\
\text { SE SLAŽE }\end{array}$} & \multirow[b]{2}{*}{ SD* } & \multirow[b]{2}{*}{ Medijan } & \multirow[b]{2}{*}{$\mathrm{S} / \mathrm{SB}$ ** } \\
\hline & $\mathbf{N}$ & $\%$ & $\mathbf{N}$ & $\%$ & $\mathbf{N}$ & $\%$ & & & \\
\hline $\begin{array}{l}\text { PU1. Korištenje } \\
\text { modula nabave je } \\
\text { učinkovito }\end{array}$ & 10 & .37 & 10 & .37 & 7 & .26 & 0,785674201 & 2,888888889 & \multirow{3}{*}{$.76 / .65$} \\
\hline $\begin{array}{l}\text { PU2. Korištenje } \\
\text { modula katalogiza- } \\
\text { cije je učinkovito }\end{array}$ & 0 & .0 & 2 & .08 & 25 & .92 & 0,630718014 & 4,481481481 & \\
\hline $\begin{array}{l}\text { PU3. Korištenje } \\
\text { modula cirkulacije } \\
\text { je učinkovito }\end{array}$ & 0 & .0 & 6 & .22 & 21 & .78 & 0,692899516 & 4,037037037 & \\
\hline $\begin{array}{l}\text { IK1. Namjeravam } \\
\text { koristiti modul } \\
\text { nabave }\end{array}$ & 14 & .52 & 8 & .25 & 6 & .23 & 1,101190278 & 2,481481481 & \multirow{3}{*}{$.75 / .78$} \\
\hline $\begin{array}{l}\text { IK2. Namjeravam } \\
\text { koristiti modul } \\
\text { katalogizacije }\end{array}$ & 0 & .0 & 9 & .23 & 18 & .67 & 0,471404521 & 4,666666667 & \\
\hline $\begin{array}{l}\text { IK3. Namjeravam } \\
\text { koristiti modul } \\
\text { cirkulacije }\end{array}$ & 0 & .0 & 10 & .37 & 17 & .63 & 0,561694477 & 4,592592593 & \\
\hline $\begin{array}{l}\text { PLK 1. Lako je } \\
\text { koristiti modul } \\
\text { nabave }\end{array}$ & 19 & .75 & 8 & .25 & 0 & .0 & 0,617530815 & 1,37037037 & \multirow{3}{*}{$.75 / .78$} \\
\hline $\begin{array}{l}\text { PLK 2. Lako je } \\
\text { koristiti modul } \\
\text { katalogizacije }\end{array}$ & 0 & .0 & 11 & .40 & 16 & .60 & 0,656297968 & 3,703703704 & \\
\hline $\begin{array}{l}\text { PLK 3. Lako je } \\
\text { koristiti modul } \\
\text { cirkulacije }\end{array}$ & 13 & .48 & 7 & .26 & 7 & .26 & 1,019696289 & 2,814814815 & \\
\hline $\begin{array}{l}\text { PKS1. WebPAC je } \\
\text { kvalitetan }\end{array}$ & 5 & .18 & 13 & .48 & 9 & .34 & 0,785674201 & 3,111111111 & \multirow{3}{*}{$.65 / .65$} \\
\hline $\begin{array}{l}\text { PKS2. Servisi su } \\
\text { kvalitetni }\end{array}$ & 11 & .40 & 5 & .20 & 11 & .40 & 1,214905146 & 2,925925926 & \\
\hline $\begin{array}{l}\text { PKS3. Mrežni por- } \\
\text { tal je kvalitetan }\end{array}$ & 4 & .15 & 3 & .10 & 20 & .75 & 1,003423495 & 3,740740741 & \\
\hline
\end{tabular}




\begin{tabular}{|c|c|c|c|c|c|c|c|c|c|}
\hline & \multicolumn{2}{|c|}{$\begin{array}{l}\text { NE SLA- } \\
\text { ŽE SE }\end{array}$} & \multicolumn{2}{|c|}{\begin{tabular}{|c|} 
DJELO- \\
MIČNO \\
SE SLAŽE
\end{tabular}} & \multicolumn{2}{|c|}{$\begin{array}{c}\text { U POT- } \\
\text { PUNOSTI } \\
\text { SE SLAŽE }\end{array}$} & \multirow[b]{2}{*}{ SD* } & \multirow[b]{2}{*}{ Medijan } & \multirow[b]{2}{*}{$\hat{L} / \mathrm{SB} * *$} \\
\hline & $\mathbf{N}$ & $\%$ & $\mathbf{N}$ & $\%$ & $\mathbf{N}$ & $\%$ & & & \\
\hline $\begin{array}{l}\text { ZS1. Redaktorski } \\
\text { nadzor }\end{array}$ & 2 & .08 & 9 & .36 & 15 & .56 & & 3,62962963 & \multirow{3}{*}{$.70 / .70$} \\
\hline $\begin{array}{l}\text { ZS2. Stručna po- } \\
\text { drška sustava je } \\
\text { zadovoljavajuća }\end{array}$ & 1 & .03 & 6 & .23 & 20 & .74 & & 4,074074074 & \\
\hline $\begin{array}{l}\text { ZS3. Edukacija za } \\
\text { sustav je zadovolja- } \\
\text { vajuća }\end{array}$ & 3 & .13 & 13 & .47 & 11 & .40 & & 3,37037037 & \\
\hline$\kappa / \mathrm{SB}^{* *}$ & & & & & & & & & $.79 / .83$ \\
\hline
\end{tabular}

* Standardna devijacija

** Cronbach alfa koeficijent / Spearman-Brownov koeficijent pouzdanosti

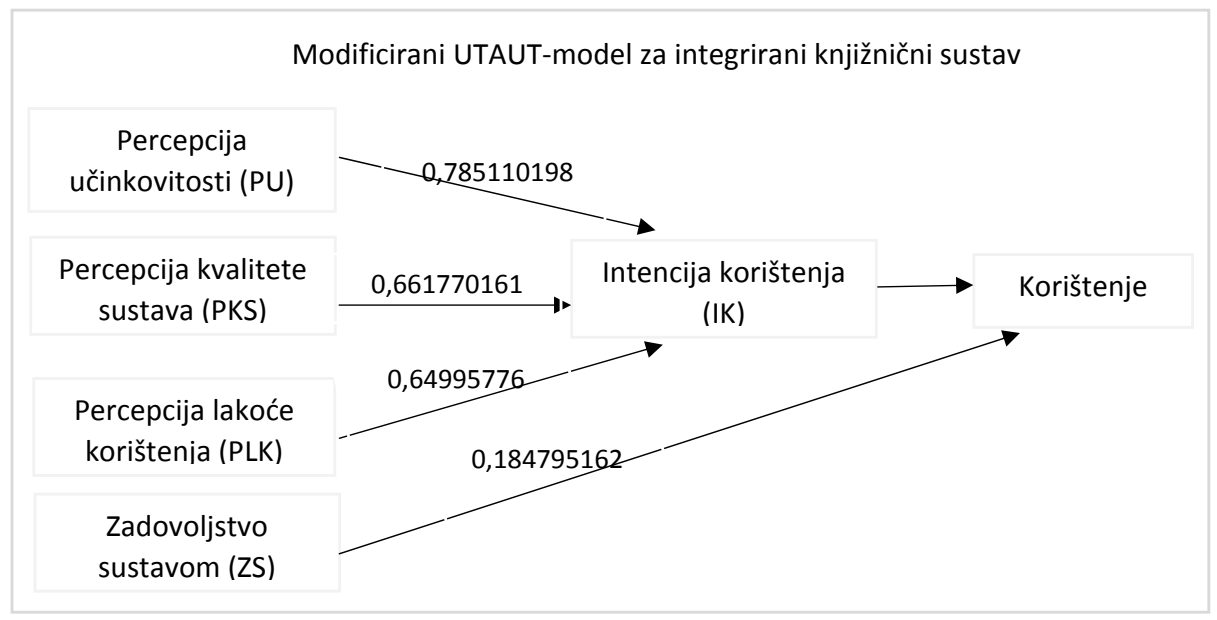

Slika 5. Modificirani UTAUT-model za integrirani knjižnični sustav Aleph 


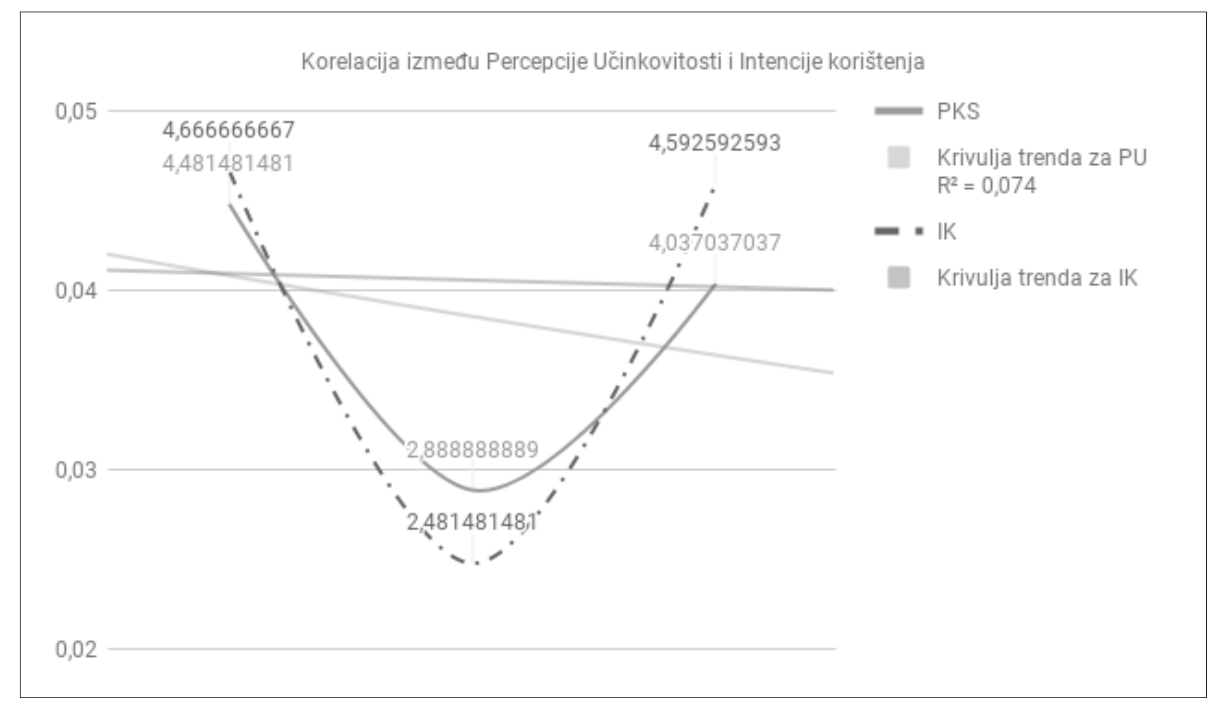

Slika 6. Pearsonov koeficijent korelacije između konstrukata Percepcije učinkovitosti i Intencije korištenja sustava

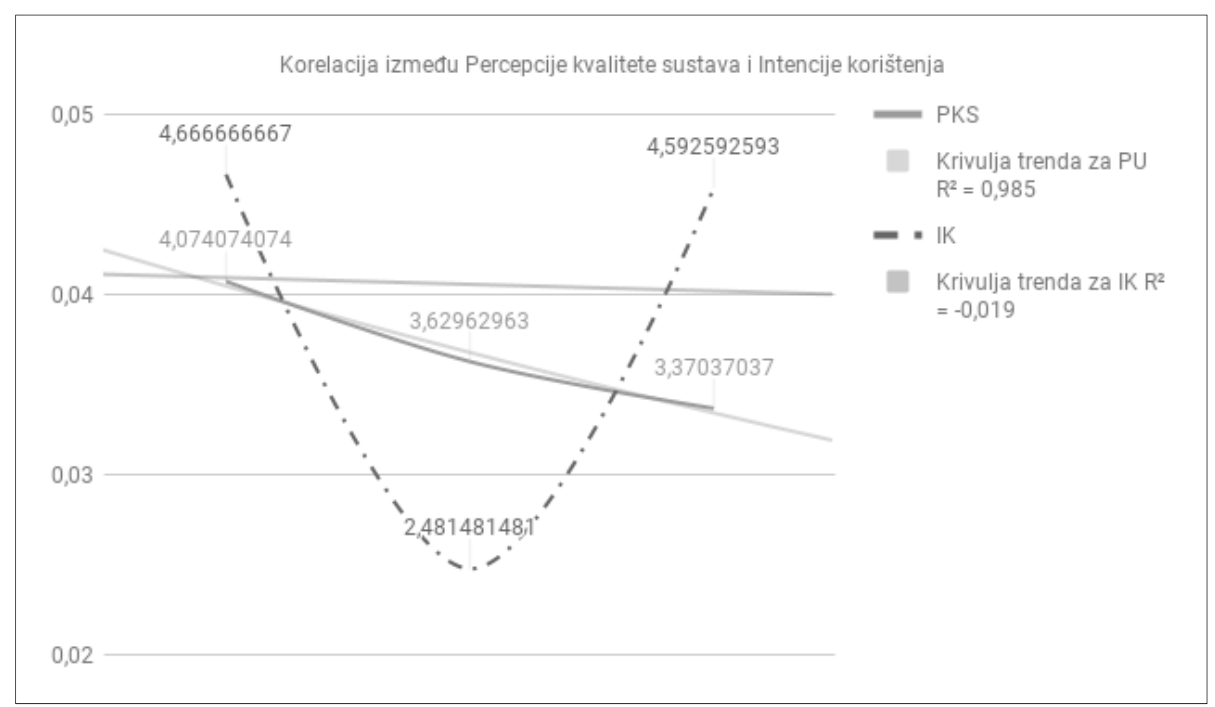

Slika 7. Pearsonov koeficijent korelacije između konstrukata Percepcije kvalitete sustava i Intencije korištenja. 


\section{Diskusija}

Istraživanje korištenja, prihvaćanja i namjere daljnjeg korištenja knjižničnog informacijskog sustava Aleph te utvrđivanje dimenzija uspješnosti nastojali smo obuhvatiti holistički, tj. iz perspektive korisničkog i sistemskog pristupa.$^{49}$ Istraživanje je obuhvatilo analizu kvantitativnih pokazatelja koje su ispitanici, tj. sustav, iskazivali u odnosu na pojedine elemente sustava koji se mogu podvesti pod dimenzije kvalitete informacija, kvalitete sustava, kvalitete usluge, korištenja (namjere korištenja), zadovoljstva korisnika i koristi, tj. dobiti. Dobivene rezultate analizirat ćemo u odnosu na tri početna istraživačka pitanja: P 1. Koriste li integrirane visokoškolske knjižnice i u kojoj mjeri prihvaćaju integrirani knjižnični sustav Aleph? P 2. Koji čimbenici utječu na namjeru integriranih knjižnica da nastave koristiti integrirani knjižnični sustav Aleph? P 3. Koja je mjera uspješnosti integriranog knjižničnog sustava Aleph?

P 1. Koriste li integrirane visokoškolske knjižnice zajednički integrirani knjižnični sustav Aleph i može li se utvrditi mjera prihvaćanja integriranog knjižničnog sustava Aleph?

Prema rezultatima korištenja programskih modula integriranog knjižničnog sustava Aleph, sve knjižnice koriste sustav u segmentu bibliografske kontrole, a u tom je segmentu izražena i najveća namjera knjižnica da dodatno pojačaju korištenje sustava. $\mathrm{S}$ obzirom na mali broj knjižnica koje koriste modul nabave $(\mathrm{N}=5)$ te velik broj onih knjižnica koje tek planiraju početi koristiti modul cirkulacije $(N=17)$, možemo zaključiti kako proces cjelovite automatizacije nije dovršen, tj. kako poslovanja integriranih knjižnica nisu u cijelosti automatizirana. Premda knjižnice izražavaju relativno dobru ocjenu zadovoljstva korištenja modula katalogizacije (3.5), vidljivo je zadržavanje broja izrađenih bibliografskih zapisa nešto ispod prosjeka. Međutim sustav bilježi povećanje broja novoizrađenih zapisa o posjedovanju i zapisa o primjerku, što ukazuje na povećani angažman knjižničara u osiguranju dostupnosti i pristupa građi krajnjim knjižničnim korisnicima. Također, 60 \% knjižnica $(\mathrm{N}=17)$ izražava namjeru snažnijeg korištenja modula cirkulacije u budućnosti. Navedeni rezultati u određenoj mjeri odstupaju od zaključaka do kojih je došla Borgman ${ }^{50}$ istražujući proces automatizacije na samom njegovu početku, pri čemu su knjižnice izrazile da im je pet osnovnih ciljeva automatizacije upotreba sustava koji podržava lokalno primjenjiva kataložna pravila i bibliografski format, da sustav podržava dijakritički set znakova, da je sistem jednostavan za korištenje korisnicima knjižnice i da osigurava povezivanje knjižnica s međunarodnim računalnim sustavima i mrežama te, posljednje, da omogućuje povezivanje s knjižnicama u zemlji. Mogao bi se predložiti zaključak da integrirane knjižnice ne doživljavaju izazovnim temeljna pitanja iz područja sistemsko-

49 Usp. Saračević, T. Nav. dj., str. 363-364.

50 Usp. Borgman, C. L., Nav. dj., str. 261. 
ga knjižničarstva, već svoja stremljenja ulažu u osiguravanje veće dostupnosti i pristupa građi. Utemeljenje za predloženi zaključak nalazimo i u činjenici da su knjižnice najvišim ocjenama ocijenile zadovoljstvo sustavom za podršku (4.1) te kvalitetu i dostupnost uputa za rad i priručnika (3.9). No da je istraživanje obuhvatilo i mišljenja knjižničara Nacionalne i sveučilišne knjižnice u Zagrebu, koji koordiniraju sistemskim procesima integriranog knjižničnog sustava Aleph, rezultati bi vjerojatno bili drukčiji.

P 2. Koji čimbenici utječu na namjeru integriranih knjižnica da nastave koristiti integrirani knjižnični sustav Aleph?

Rezultati korelacijske analize (slika 5) pokazuju značajnu statističku povezanost, tj. korelaciju između konstrukata Percipirana učinkovitost, Percepcija kvalitete sustava i Percepcija lakoće korištenja s konstruktom Intencija korištenja. Konstrukt Zadovoljstvo sustavom ne iskazuje statistički značajnu povezanost, tj. korelaciju s namjerom knjižničara da koriste integrirani knjižnični sustav Aleph. Zaključujemo da taj konstrukt pospješuje samo korištenje, ali nema odlučujuću ulogu u budućoj namjeri, odnosno intenciji nastavka korištenja integriranog knjižničnog sustava Aleph. Rezultate je važno sagledati u odnosu na činjenicu da su knjižničari u određenoj mjeri obvezni koristiti integrirani knjižnični sustav, odnosno nemaju preveliku mogućnost izbora programa kako bi osobno zadovoljstvo korištenjem ili lakoćom korištenja moglo utjecati na krajnji izbor. Važno je naglasiti da se motivacija za korištenje integriranog knjižničnog sustava te ulaganja $\mathrm{u}$ automatizaciju knjižničnog poslovanja najizrazitije prepoznaje u percepciji, tj. očekivanoj učinkovitosti samog programa te, posljedično, učinkovitosti usluga same knjižnice. Takav zaključak komplementaran je rezultatima kvantitativne analize koji su pokazali da korištenje integriranog knjižničnog sustava rezultira povećanjem razine usluga knjižnica.

P 3. Možemo li govoriti o mjeri, tj. dimenzijama uspješnosti integriranog knjižničnog sustava?

Rezultati istraživanja pokazali su da postoji značajna statistička korelacija između percepcije knjižničara o učinkovitosti korištenja integriranog knjižničnog sustava i namjere knjižničara da prihvate i nastave koristiti integrirani knjižnični sustav (slika 6). Također, uočava se statistički značajna korelacija između ocjene kvalitete programskog modula i plana daljnjeg korištenja tog programskog modula u budućnosti (tablica 4 i slika 7). Namjera snažnijeg korištenja integriranog knjižničnog sustava Aleph usmjerena je na povećanje razine usluga (povećanje posudbe građe) samih knjižnica. S obzirom na visoku ocjenu onih elemenata knjižničnog informacijskog sustava Aleph (tablica 5) koji rasterećuju rad knjižničara u segmentu sistemskoga knjižničarstva te razvoja bibliografske kontrole (primjena zajedničkih pravilnika za rad, sustav za podršku, redakcijski nadzor) i 
razvoja ljudskih kapaciteta (edukacija za rad u sustavu), knjižnice se usmjeruju na osnaživanje dostupnosti i pristupa informacija svojim korisnicima.

Izraženo u dimenzijama i atributima teorijskog D\&M-modela vrednovanja uspješnosti informacijskog sustava ${ }^{51}$, možemo zaključiti kako integrirani knjižnični sustav Aleph iskazuje relativno dobru ocjenu kvalitete sustava, s izraženim zahtjevima prema osnaživanju sustava u segmentu kvalitete informacija (cjelovita automatizacija, redakcijski nadzor, edukacija) te kvalitete usluge (WebPAC, mrežni servisi). Ono što DeLone i McLean nazivaju dobit informacijskog sustava, u našem je primjeru prepoznato u segmentu povećanja učinkovitosti integriranih knjižnica. Možemo stoga pretpostaviti kako bismo mjeru uspješnosti informacijskog sustava integriranog knjižničnog sustava Aleph mogli tražiti u segmentu povećanja knjižnične učinkovitosti te razvoja knjižničnih usluga, a koje nastaju kao rezultat korištenja knjižničnog informacijskog sustava. Predloženu pretpostavku potrebno je potvrditi namjenski dizajniranim upitnikom sukladno metodologiji D\&M IS-modela u okviru zasebnog istraživanja uspješnosti integriranog knjižničnog sustava Aleph.

\section{Zaključak}

Automatizacija knjižničnog poslovanja iznimno je složen i zahtjevan proces, a vrednovanje njegovih učinaka zahtijeva veliku pozornost kako samih knjižničara tako i kreatora razvojnih politika. Rad nastoji dati prilog višedimenzionalnim istraživanjima u području procjene uspješnosti informacijskih sustava na primjeru integriranog visokoškolskog knjižničnog sustava Aleph.

Istraživanju procjene uspješnosti informacijskog sustava pristupilo se višedimenzionalnim pristupom, analizirajući korištenje i prihvaćanje integriranog knjižničnog sustava Aleph primjenom modificiranog UTAUT-modela te procjenjujući prikladnost integriranog knjižničnog sustava Aleph mogućem vrednovanju sukladno modelu uspješnosti informacijskih sustava DeLonea i McLeana. Prema Saračeviću ${ }^{52}$, sistemskim pristupom analizirani su kvantitativni podaci o veličini, značajkama i aktivnostima sustava, dok se za korisnički pristup primijenila prediktivna metoda istraživanja prihvaćanja i korištenja tehnologije prema testiranom modificiranom UTAUT-modelu. Zaključke bi bilo potrebno potvrditi primjenom namjenski dizajniranog metodološkog upitnika sukladno UTAUT-modelu te D\&M IS-modelu.

Istraživanje je također bilo ograničeno samo na analizu korisnika sustava ZAG te bi za prikaz cjelovitije slike bilo potrebno uključiti i ispitivanje stavova knjižničara sustava NSK. Veća stratifikacija ispitnog uzorka u odnosu na vrstu knjižnice, radni status ispitanika, prethodno iskustvo i sl. također bi bila poželjna.

51 Usp. DeLone, W. H.; E. R. McLean. Nav. dj., 2003.

52 Usp. Saračević, T., Nav. dj., 363-364. 


\section{LITERATURA}

Ajzen, I.; M. Fishbein. Understanding attitudes and predicting social behavior. Englewood Cliffs, NJ : Prentice-Hall, 1980.

Ajzen I. The theory of planned behavior. // Organizational Behavior and Human Decission Processess 50, (1991), 179-211.

The ALA glossary of library and information science. / Heartsill Young (ed.). Chicago: American Library Association, 1983.

Badurina, B. Model prihvaćanja novih tehnologija za učenje na daljinu na hrvatskim sveučilištima : doktorska disertacija. Zagreb: Filozofsko fakultet Sveučilišta, 2010.

Borgman, C. L. Automation is the answer, but what is the question? Progress and prospects for Central and Eastern European Libraries. // Journal of Documentation 52, 3(1996), 252-295.

Choi, Y.; E. Rasmussen, What qualifications and skills are important for digital librarian positions in academic libraries? A job advertisment analysis. // The Journal of Academic Librarianship 35, 5(2009), 457-467.

Czaikowski Underhill, M.; L. Burkey Wade. Making a career shift. // Jump-start your career as a digital librarian: a LITA guide / edited by Jane Monson. Chicago : ALA, 2013. Str. 59-72.

Članovi skupine za uvođenje knjižničnog sustava Voyager u knjižnice sveučilišta u Hrvatskoj. [citirano: 2018-06-08]. Dostupno na: http://stari.nsk.hr/di/knjizvoy.asp.

Davis, F. D. Perceived usefulness, perceived ease of use, and user acceptance of information technology. // MIS Quarterly 13, 3(1989), 319-340.

DeLone W. H.; E. R. McLean. Information systems success: the quest for the dependent variable. // Information Systems Research 3, 1(1992), 60-95.

DeLone, W. H.; E. R. McLean. Information systems success revisited. // Proceedings of the 35th Hawaii International Conference on System Sciences / ed. Sprague Jr R. H. IEEE Computer Society, Hawaii, US, 2002. Str. 2966-2976. Doi: 10.1109/ HICSS.2002.994345.

DeLone, W. H.; E. R. McLean. The DeLone and McLean model of information systems success: a ten-year update. // Journal of Management Information Systems 19, 4(2003), 9-30.

Fishbein, M.; I. Ajzen. Belief, attitude, intention and behavior: an introduction to theory and research, reading. MA: Addison-Wesley, 1975.

Giunio; K.; D. Polanski; M. Šupraha-Perišić. Kooperativna katalogizacija u knjižničnom sustavu ZaKi: u praksi mreže knjižnica. // Vjesnik Bibliotekara Hrvatske 58, 1-2(2015), 189-208. [citirano 2018-03-31]. Dostupno na: http://www.hkdrustvo.hr/ vjesnik-bibliotekara-hrvatske/index.php/vbh/article/view/62/57. 
Horsfall, J. The Human impact of library automation. [citirano: 2018-03-31]. Dostupno na: http://web.simmons.edu/ chen/nit/NIT\%2792/195-hor.htm.

IFLA Manifest o knjižničnoj statistici. // Vjesnik bibliotekara Hrvatske 55, 1(2012), 137-140.

Integralni informacijski sustav NSB / izradili L. Jelenković, V. Lešaja, I. Mihel, Ž. Rajter, D. Skender, J. Stipanov, M. Willer. Zagreb: Nacionalna i sveučilišna knjižnica, 1990.

Jantz, R. C. Innovation in academic libraries: an analysis of university librarians' perspectives. // Library \& Information Science Research 34, (2012), 3-12.

Krelja Kurelović, E. Prihvaćanje otvorenog pristupa znanstvenim informacijama i obrazovnim sadržajima u hrvatskoj akademskoj zajednici : doktorski rad. Zagreb: Filozofski fakultet Sveučilišta, 2017.

Line, M. B. Forty years of library automation: a personal reflection. // Program 40, 2(2006), 118-122.

Lynch, C. From automation to transformation: forty years of libraries and information technology in Higher education. // EDUCAUSE Review 35, 1(2000), 60-68.

Macan, B.; G. V. Fernández; J. Stojanovski. Open source solutions for libraries: ABCD vs Koha. // Program 47, 2(2013), 136-154.

Machala, D. Integrirani knjižnični sustav Nacionalne i sveučilišne knjižnice u Zagrebu te visokoškolskih i znanstvenih knjižnica RH : konferencija korisnika, Zagreb, 4. listopada 2011. [citirano: 2018-05-31]. Dostupno na: http://iks.nsk.hr/wp-content/ uploads/2011/09/Integrirani-knji\%C5\%ni\%C4\%8Dni-sustavDM1.pptx.

Machala, D.; L. Machala. Implementacija integriranog knjižničnog sustava Aleph u Nacionalnoj i sveučilišnoj knjižnici u Zagrebu i knjižnicama sastavnicama Sveučilišta u Zagrebu i znanstvenih instituta : posebnosti implementacijskog procesa. // Zbornik radova 12. dana specijalnih i visokoškolskih knjižnica, Opatija, 11.-14. svibnja 2011. Zagreb : Hrvatsko knjižničarsko društvo, 2013. Str. 330-343.

Mfengu, A. Y. Analysis of the approaches of senior management teams towards adoption of next generation library management systems: a case study of Cape Library consortium institutions. Cape Town : University, 2014.

Mohideen, Z. A. Librarian's acceptance of open source library information system using the OSIS-UTAUT model: doctoral thesis. Kuala Lumpur: Faculty of Computer Science and Information Technology, Unversity of Malaya, 2017.

Mrežni portal Integrirani knjižnični sustav - IKS. [citirano: 2018-05-31]. Dostupno na: http://iks.nsk.hr.

Petter, S.; W. DeLone; E. McLean. Measuring information systems success : models, dimensions, measured, and interrelationships. // European Journal of Information Systems 17(2008), 236-263. 
Rabina, D. L.; D. J. Walczyk. Information professionals' attitude toward the adoption of innovations in everyday life. // Information Research 12, 4(2007). [citirano: 201803-31]. Dostupno na: http://InformationR.net/ir/12-4/colis12.html.

Ratledge, D. C. Sproles. An analysis of changing role of systems librarians. // Library Hi Tech 35, 2(2017), 303-311.

Saračević, T. Digital library evaluation : toward an evolution of concepts'. // Library trends 49, 3(2000), 350-369.

Siegle, D. Instrument reliability. // University of Connecticut. [citirano:2018-06-08]. Dostupno na: https://researchbasics.education.uconn.edu/instrument_reliability/.

Skender, D.; M. Willer. Computer-based library systems in the National and University Library in Zagreb. // Program 20, 1(1986), 82-85.

Sporazum o uređivanju odnosa NSK i sudionika u Integriranom knjižničnom sustavu temeljenom na zajedničkom knjižničnom programu. Zagreb: Nacionalna i sveučilišna knjižnica u Zagrebu, 2011.

Srića, V.; M. Spremić. Informacijskom tehnologijom do poslovnog uspjeha. Zagreb: Sinergija, 2000.

Venkatesh, V.; M. G. Morris; G. B. Davis; F. D. Davis. User acceptance of information technology: toward a unified view. // MIS Quarterly 27, 3(2003), 425-478.

Venkatesh, V.; J. Y. L. Thong; X. Xu. Consumer acceptance and use of information technology : extending the Unified theory of acceptance and use of technology. // MIS Quarterly 36, 1(2012), 157-178.

Venkatesh, V.; J. Y. L. Thong; X. Xu. Unified theory of acceptance and use of techno$\log$ : a synthesis and the road ahead. // Journal of the Association for Information Systems 17, 5(2016), 323-376.

Vrkić, D.; J. Lisek; M. Glavica. Zaplesala je ovo ljeto: implementacija Kohe u knjižnični sustav Fakulteta elektrotehnike i računarstva : prvi dio. // Vjesnik bibliotekara Hrvatske 55, 3-4(2013), 1-16.

Weerasinghe, S.; M. Hindagolla. Technology acceptance model in the domains of LIS and education: a review of selected literature. // Library Philosophy and Practice (e-journal). 2017). [citirano: 2018-03-31]. Dostupno na: http://digitalcommons.unl. edu/libphilprac/1582.

Willer, M. CROLIST: Croatian library and information system. // VINE 24, 4(1994), 39-44.

Williams, M. D.; P. R. Nripendra; Y. K. Dwivedi. The Unified Theory of Acceptance and Use of Technology (UTAUT): a literature review. // Journal of Enterprise Information Management 28, 3(2015), 443-488. 